\title{
Cannabidiol as a Therapeutic Target: Evidence of its Neuroprotective and Neuromodulatory Function in Parkinson's Disease
}

\section{OPEN ACCESS}

Edited by:

Gustavo Gonzalez-Cuevas, Idaho State University, United States

Reviewed by:

Xavier Nadal Roura, Independent researcher, Córdoba,

Spain

Teresa Morera-Herreras, University of the Basque Country,

Spain

*Correspondence:

Illhuicamina Daniel Limón

ilhlimon@yahoo.com.mx

daniel.limon@correo.buap.mx

Specialty section: This article was submitted to

Neuropharmacology,

a section of the journal

Frontiers in Pharmacology

Received: 17 August 2020 Accepted: 16 November 2020 Published: 15 December 2020

Citation:

Patricio F, Morales-Andrade AA, Patricio-Martínez A and Limón ID (2020) Cannabidiol as a Therapeutic Target: Evidence of its Neuroprotective and

Neuromodulatory Function in

Parkinson's Disease.

Front. Pharmacol. 11:595635. doi: 10.3389/fphar.2020.595635

\author{
Felipe Patricio ${ }^{1}$, Alan Axel Morales-Andrade ${ }^{1}$, Aleidy Patricio-Martínez ${ }^{1,2}$ and \\ Ilhuicamina Daniel Limón ${ }^{1 *}$ \\ ${ }^{1}$ Laboratorio De Neurofarmacología, Facultad De Ciencias Químicas, Benemérita Universidad Autónoma de Puebla, Puebla, \\ Mexico, ${ }^{2}$ Facultad De Ciencias Biológicas, Benemérita Universidad Autónoma de Puebla, Puebla, Mexico
}

The phytocannabinoids of Cannabis sativa L. have, since ancient times, been proposed as a pharmacological alternative for treating various central nervous system (CNS) disorders. Interestingly, cannabinoid receptors (CBRs) are highly expressed in the basal ganglia (BG) circuit of both animals and humans. The BG are subcortical structures that regulate the initiation, execution, and orientation of movement. CBRs regulate dopaminergic transmission in the nigro-striatal pathway and, thus, the BG circuit also. The functioning of the $B G$ is affected in pathologies related to movement disorders, especially those occurring in Parkinson's disease (PD), which produces motor and non-motor symptoms that involving GABAergic, glutamatergic, and dopaminergic neural networks. To date, the most effective medication for PD is levodopa (L-DOPA); however, long-term levodopa treatment causes a type of long-term dyskinesias, L-DOPAinduced dyskinesias (LIDs). With neuromodulation offering a novel treatment strategy for PD patients, research has focused on the endocannabinoid system (ECS), as it participates in the physiological neuromodulation of the $B G$ in order to control movement. CBRs have been shown to inhibit neurotransmitter release, while endocannabinoids (eCBs) play a key role in the synaptic regulation of the BG. In the past decade, cannabidiol (CBD), a non-psychotropic phytocannabinoid, has been shown to have compensatory effects both on the ECS and as a neuromodulator and neuroprotector in models such as 6-hydroxydopamine (6-OHDA), 1-methyl-4-phenyl1,2,3,6-tetrahydropyridine (MPTP), and reserpine, as well as other PD models. Although the CBD-induced neuroprotection observed in animal models of PD has been attributed to the activation of the CB1 receptor, recent research conducted at a molecular level has proposed that CBD is capable of activating other receptors, such as CB2 and the TRPV-1

\footnotetext{
Abbreviations: 2-AG 2-arachidonoyl-glycerol; 6-OHDA 6-hydroxydopamine; AEA, anandamide; BG, basal ganglia; CB1, cannabinoid receptor type-1; CB2, cannabinoid receptor type-2; CBD, cannabidiol; CBDA, cannabidiol acid; CBRs, cannabinoid receptors; $\mathrm{CPu}$, caudate-putamen; eCBs, endocannabinoids; ECS, endocannabinoid system; FAAH, fatty acid amide hydrolase; GPe, globus pallidus external; GPi, globus pallidus internal; GPR55, G protein receptor-55; 1-DOPA Levodopa; LID 1-DOPA-induced dyskinesia; MPTP 1-Methyl-4-phenyl-1,2,3,6-tetrahydropyridine; PD, Parkinson's disease; PPAR- $\gamma$, Peroxisome proliferator-activated gamma; SNpc, substantia nigra pars compacta; SNpr, substantia nigra pars reticulata; STN, subthalamic nucleus; THC $\Delta$-tetrahydrocannabinol; THCA $\Delta 9$-tetrahydrocannabinol acid; TRPV-1, transient receptor potential vanilloid-1.
} 
receptor, both of which are expressed in the dopaminergic neurons of the nigro-striatal pathway. These findings open new lines of scientific inquiry into the effects of CBD at the level of neural communication. Cannabidiol activates the PPAR $\gamma$, GPR55, GPR3, GPR6, GPR12, and GPR18 receptors, causing a variety of biochemical, molecular, and behavioral effects due to the broad range of receptors it activates in the CNS. Given the low number of pharmacological treatment alternatives for PD currently available, the search for molecules with the therapeutic potential to improve neuronal communication is crucial. Therefore, the investigation of $\mathrm{CBD}$ and the mechanisms involved in its function is required in order to ascertain whether receptor activation could be a treatment alternative for both PD and LID.

Keywords: cannabidiol (CBD), neuroprotective, neuromodulatory, L-DOPA-induced dyskinesia, parkinson's diasese

\section{CANNABIDIOL: ORIGIN, PHARMACOKINETICS, AND PHARMACODYNAMICS}

Taxonomically, Cannabis sativa L. pertains to the Cannabaceae family (Russo, 2007), which has recently been found to include the genera Cannabis, Humulus, and Celtis. Cannabis sativa has three varieties, sativa, indica and ruderalis (McPartland, 2018). Phytocannabinoids are the active compounds in Cannabis sativa L., the most abundant compound of which is $\Delta^{9}$ tetrahydrocannabidiol (THC), which has psychoactive pharmacological effects, while cannabidiol (CBD), its second most abundant compound, has psychoactive/non-psychotropic pharmacological effects and is more medically promising than THC (Ibeas Bih et al., 2015) (Figure 1). THC and CBD are initially formed as carboxylic acids (e.g., $\Delta^{9}$ - THCA, CBDA) that are decarboxylated into neutral form, a process occurring naturally as the plant ages and when it is exposed to light or heat (Hanuš et al., 2016; Wang et al., 2016).

While preclinical and clinical studies have shown that THC induces anxiety and psychotic symptoms in healthy subjects, the consumption of CBD has been found to significantly reduce the effects of THC, with CBD shown to have an antagonistic effect against THC (Dalton et al., 1976; Zuardi et al., 2006). Interestingly, both compounds have been shown to affect inflammation, anxiety, emesis, and nausea; moreover, it has been proposed that they act as both neuroprotective agents and antioxidants (Pertwee 2004; Cascio and Pertwee, 2014).
The strategic use of both compounds has been reported for pain relief in cancer and neuropathic pain relief in multiple sclerosis (Zajicek and Apostu, 2011; Fine and Rosenfeld, 2014; Dariš et al., 2019). Studies on CBD have shown that it participates in the regulation of the endocannabinoid system (ECS), the important characteristics of which will be summarized in this review.

The ECS is a complex lipid network consisting of cannabinoid receptors (CBRs), endogenous ligands, and the enzymes involved in endocannabinoid degradation and synthesis (Figure 2). Chemicals derived from fatty acid amides and diacylglycerols, endocannabinoids (eCBs) are synthesized endogenously in mammals and are produced on demand in response to increased intracellular calcium levels $\left(\left[\mathrm{Ca}^{2+}\right]_{\mathrm{i}}\right.$ ) (Di Marzo et al., 1998; Mechoulam and Parker, 2013). The main eCBs are arachidonoylethanolamine, also known as anandamide (AEA), and 2-arachidonoyl-glycerol (2-AG) (Devane et al., 1992; Mechoulam et al., 1995; Sugiura et al., 1995).

The synthesis of AEA is produced by the hydrolysis of a phospholipid precursor, N-acyl-phosphatidylethanolamine (NAPE), which is carried out by the enzyme $\mathrm{N}$-acylphosphatidylethanolamine-phospholipase D (NAPE-PLD). There is evidence that AEA is formed from $\mathrm{N}$-acyllysophosphatidylethanolamine (NALPE) by the enzymes lysophospholipase D (lysoPLD), $\alpha / \beta$-hydrolase 4 (ABH4), and phospholipase $\mathrm{C}$ (PLC). The other eCB, 2-AG, is synthetized via the activation of a PLC, thus producing 1,2-diacylglycerol (DAG), which, in turn, is converted into $2-A G$ by diacylglycerol lipase

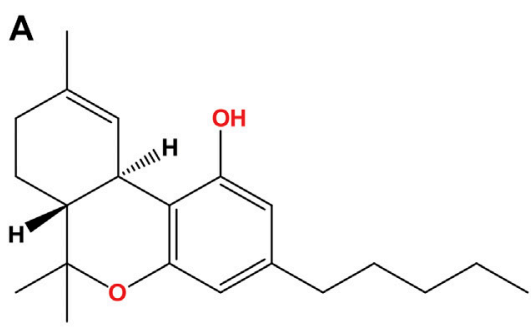

$\Delta^{9}$-Tetrahydrocannabinol

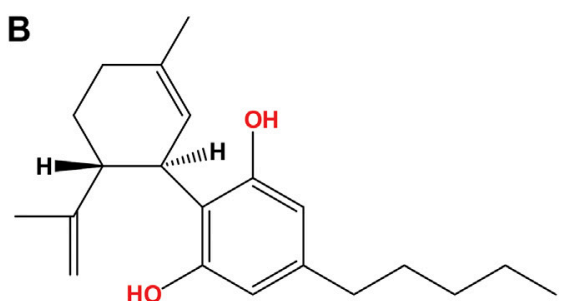

Cannabidiol

FIGURE 1 | Chemical structures, (A) THC and (B) CBD, the main phytocannabinoids extracted from the Cannabis plant THC, tetrahydrocannabinol; CBD, cannabidiol. 


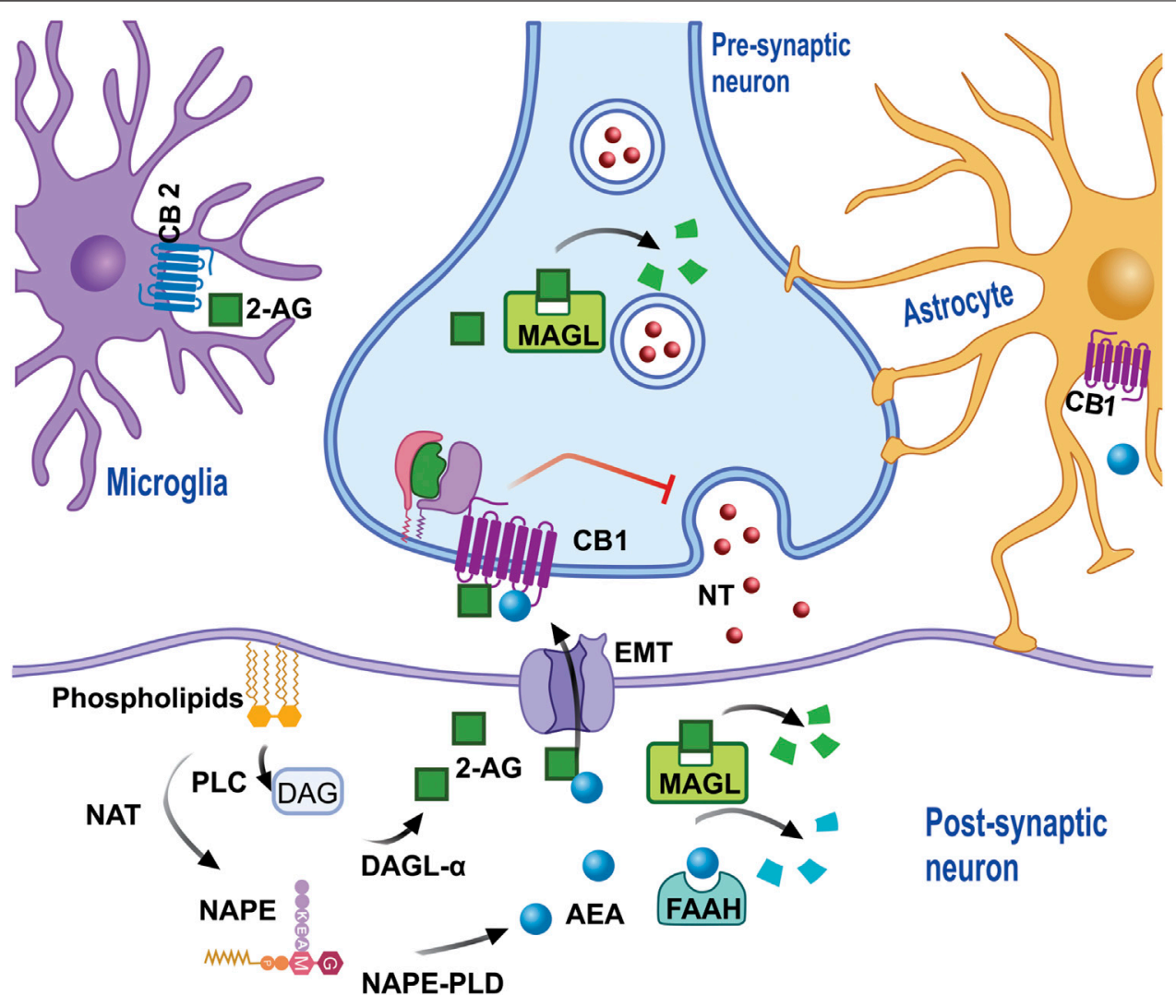

FIGURE 2 l eCB is synthesized from membrane phospholipids. NAT synthesizes the precursor NAPE, which subsequently, through the action of PLD, produces AEA in the cytoplasm of the post-synaptic neuron (or neuron spine). AEA leaves the cytoplasm and enters the synaptic space via diffusion and/or the action of EMT in order that, once it has onside, AEA activates the cannabinoid receptors which inhibit the release of NT. The degradation of AEA in EMT is regulated by FAAH, which produces metabolites such as AA and ETA. 2-AG requires the formation of the DAG precursor by PLC, which then through the action of diacylglycerol lipase $\alpha$, and together with arachidonic acid generates 2-AG, which then leaves the synaptic space to activate cannabinoid receptors, which are also present in the microglia and/or astrocytes, and can be degraded by MAGL both in the pre and post-synapse, generating AA and Gro as metabolites. Abbreviations: eCB, endocannabinoids; NAT, $\mathrm{N}$-acyl transferase; NAPE, N-acyl-phosphatidylethanolamine; PLD, phospholipase D; AEA, anandamide; NT, neurotransmitters; EMT, endocannabinoid membrane transporter; FAAH, fatty acid amide hydrolase; AA, arachidonic acid; ETA, ethanolamine; 2-AG, 2- Arachidonoylglycerol; DAG, diacylglycerol; PLC, phospholipase C; MAGL, monoacylglycerol lipase.

(DAGL), which can also be synthesized from sn-1lysophospholipids, via the sequential action of phospholipase A1 (PLA1) and lysophospholipase C (Di Marzo et al., 2015). The main degradation enzymes of the eCBs are fatty acid amide hydrolase (FAAH) and monoacylglycerol lipase (MAGL). FAAH is located in both the Soma and the post-synaptic neuronal dendrites and is associated with the membranes of cytoplasmic organelles that serve as a reservoir of $\left[\mathrm{Ca}^{2+}\right]_{\mathrm{i}}$, the mitochondria, and the smooth endoplasmic reticulum. DAGL and MAGL are located in the postsynaptic dendrites and the pre-synaptic neurons, respectively, whit the latter expressed when 2-AG, the main substrate, is metabolized. Both AEA and 2-AG are metabolized by FAAH, with other enzymes, such as the $\alpha / \beta$-hydrolase families 6 and 12 (ABHD6 and ABHD12), also participating, although to a lesser extent $(<10 \%)$ (Mechoulam and Parker, 2013).

Unlike the classical form of neurotransmitter release, eCBs are released from the post-synaptic neuron to then interact with its specific receptors in a retrograde manner (Di Marzo et al., 1998;
Di Marzo et al., 2015). It has been proposed that the release of eCBs, but mainly AEA, occurs via a transporter called the endocannabinoid membrane transporter: (Yates and Barker, 2009; Fowler 2013). Once released into the synaptic space, these eCBs interact with their specific receptors (Figure 2). CBRs have been cloned, characterized, and classified into two subtypes, cannabinoid receptor type 1 (CB1) (Matsuda et al., 1990) and cannabinoid receptor type 2 (CB2) (Munro et al., 1993), which are proteins containing seven transmembrane domains coupled to inhibitory $\mathrm{G}$ proteins $\left(\mathrm{G} \alpha_{\mathrm{i}}\right)$. At a molecular level, CB1-receptor activation inhibits the release of presynaptic neurotransmitters via the inhibition of the enzyme adenylyl cyclase (AC), the adenylate monophosphate circle/ protein kinase A (cAMP/PKA) pathway, and the inhibition of the voltage-dependent $\mathrm{Ca}^{2+}$ channels (Mackie, 2006; Kano et al., 2009). This physiological mechanism ensures that the ECS plays a neuromodulatory role.

The pharmacokinetics of CBD is variable and depends on the route of administration (oral, intravenous, sublingual, topical, 
inhalation, and transdermal), the type of product administered, concomitant food intake, and drug-drug interactions. Pharmaceutical forms with lipid excipients have been reported to improve CBD absorption (Zgair et al., 2016), with a study, conducted on subjects who had ingested food prior to administration via an erosol containing THC/CBD, finding a five-fold increase in the area under the curve (AUC) and a threefold increase in the Cmax, as well as the prolongation of the Tmax (Stott et al., 2013). The use of sublingual drops at a dose of $20 \mathrm{mg}$ obtained a Tmax of $2.17 \mathrm{~h}$ and a Cmax of $2.05 \mathrm{ng} / \mathrm{ml}$ (Guy and Flint, 2004). Administration via inhalation obtained a Tmax of $0.17 \mathrm{~h}$ and a Cmax of $28.2 \mathrm{ng} / \mathrm{ml}$ in occasional users, while a Tmax of $0.29 \mathrm{~h}$ and a Cmax of $76.3 \mathrm{ng} / \mathrm{ml}$ were obtained in frequent users, both via the administration $1.5 \mathrm{mg}$ doses (Swortwood et al., 2017). Idiosyncratic differences mean that the mechanisms of administering cannabinoids are highly variable, with the oral administration of CBD shown to have a bioavailability of 13-19\% (Mechoulam et al., 2002). Vaporization should be considered a promising route of administration, given that it can improve bioavailability without presenting a risk to the consumer, as long as it is used correctly (Varlet et al., 2016).

Cannabidiol is mainly excreted in feces, with part of the drug excreted unchanged (Perez-Reyes et al., 1976), while approximately $100 \mathrm{CBD}$ metabolites are estimated to be excreted via the kidneys (Huestis, 2007). It is mainly metabolized via both oxidation and hydroxylation at various sites in the molecule, generating a complex degradation process. Other metabolites are formed via the $\beta$-oxidation and biotransformation of the pentyl side chain and hydroxylations at C-6 and C-7 (Harvey and Mechoulam, 1990), while the highest concentration metabolites are 7-COOH-CBD and 6- OH-CBD, which are excreted intact or as glucuronide acid conjugates (Devinsky et al., 2018).

The metabolite 7-OH-CBD has been reported to both inhibit FAAH $($ IC50 $=34 \mu \mathrm{M})$ and decrease the metabolism of AEA in a basophil culture (IC50 = 50 $\mu \mathrm{M}$ ) (Bisogno et al., 2001). Moreover, both 7-OH-CBD and 7-COOH-CBD have been reported to have anti-inflammatory effects and inhibit the production of nitric oxide (NO), reactive oxygen species (ROS), and tumor necrosis factor-alpha (TNF-a) (Mechoulam et al., 2010).

While the inhibition of the CYP1A1, 1A2, 2C9, and 1B1 isoforms has been reported, the inhibition of the CYP2C19 and 3A4 isoforms is more potent (Bornheim and Grillo, 1998; Zendulka et al., 2016; Arellano et al., 2017). This inhibition can have a synergistic effect in the presence of barbiturates (Paton and Pertwee 1972). Although CBD can interrupt the hydrolysis of THC by Cytochrome P450, no pharmacokinetic changes are reported in either compound. CBD metabolites, such as 7-OH or 7-COOH-CBD, have anti-inflammatory effects and inhibit the formation of NO, ROS, TNF- $\alpha$, IL-1ß, NF- $\kappa \beta$, and IL-6 (Watzl et al., 1991; Kozela et al., 2010; Mechoulam et al., 2010). In addition, CBD reduces the production of prostaglandins (Costa et al., 2004) and nitric oxide synthases (NOS) (Esposito et al., 2006), indicating a route for anti-inflammatory or antinociceptive effects, while one effect of 6-oxo-CBD (a CBD metabolite) is anticonvulsant activity (Carlini et al., 1975). As CBD does not affect the metabolism of 2-AG (Rimmerman et al., 2011), it does not influence the action of the $\mathrm{CB} 1$ and $\mathrm{CB} 2$ receptors. It should be noted that the effects of eCB and phytocannabinoids, especially $\mathrm{CBD}$, depend on the expression and anatomical location of CBRs in the brain.

While the mechanism of action by which CBD exerts its therapeutic effects remains, to date, unclear, the interactions between $\mathrm{CBD}$ and various molecular targets can be divided into interactions that are either dependent on or independent of the ECS. The ECS-dependent effects of CBD occur via the CB1, $\mathrm{CB} 2$, and TRPV-1 receptors, as does its interaction with the FAAH enzyme. As CBD is a lipophilic structure, it is able to cross the blood-brain barrier (BBB) and thus modulate specific zones of the CNS (Calapai et al., 2020). While CBD was thought to have a low affinity for CBRs and able to activate them at high concentrations $(>10 \mu \mathrm{M})$ (Howlett and Fleming, 1984), at low concentrations, it has been reported to act on the allosteric site of the CB1 receptor (Laprairie at al., 2015), which may maximize the binding of the orthosteric probe. At higher concentrations, meanwhile, this action may reduce the binding of the orthosteric probe, producing a bell-shaped curve (Tham et al., 2019). Cannabidiol acts as an inverse agonist on the CB1 and CB2 receptors, as demonstrated by the efficacy of its antagonist properties against the agonistic effects induced by CP55940 on the $\mathrm{CB} 1$ and $\mathrm{CB} 2$ receptors in $[35 \mathrm{~S}] \mathrm{GTP} \gamma \mathrm{S}$ binding assays undertaken on membrane preparations (Thomas et al., 2007). The $K_{B}$ values obtained for CBD as an antagonist of CP55940induced [35S]GTP $\gamma$ S binding were 79 and $65 \mathrm{nM}$ for CB1 and $\mathrm{CB} 2$, respectively, while the $\mathrm{Ki}$ values for the displacement of $[3 \mathrm{H}] \mathrm{CP} 55940$ were 4.9 and $4.2 \mu \mathrm{M}$ for CB1 and CB2, respectively (Thomas et al., 2007). These findings have been supported by recent reports showing that $\mathrm{CBD}$ does not necessarily have to be present at the orthosteric site to act as an inverse agonist, meaning that it could induce a non-competitive negative allosteric modulation of the CB1 receptor (Laprairie et al., 2015). In addition, at $100 \mathrm{nM}, \mathrm{CBD}$ was found to be a negative allosteric modulator of CB2, with a Ki value of $4.2 \mu \mathrm{M}$ observed for the displacement of WIN55212.2 (Martínez Pinilla et al., 2017). These findings demonstrate that cannabidiol is a high-potency antagonist of CBR agonists in the brain and has a negative allosteric modulatory effect (Figure 3).

It has also been reported that CBD is capable of inhibiting some of THC's effects (Zuardi et al., 1982) by acting as a negative allosteric modulator on both CB1 and CB2 (Laprairie et al., 2015; Martí nez-Pinilla et al., 2017). Furthermore, computational models have identified an allosteric site on the CB1 receptor which is able to bind with $\mathrm{CBD}$ and, thereby, promote conformational changes to the receptor in either its active or inactive state. These findings may explain the negative allosteric modulatory effects of CBD on the CB1 receptor, with the possible participation of other molecular targets (namely independent interactions in the ECS) that, together, contribute to the effects observed in both in vitro and in vivo experimental studies (Chung et al., 2019). The mechanism by which CBD functions may be explained as a biased agonism, namely that it selects "which signaling pathways become activated upon binding to the receptor". In 2018, it was reported that CBD, applied at $100 \mathrm{nM}$ concentrations, produces a biased agonism effect 


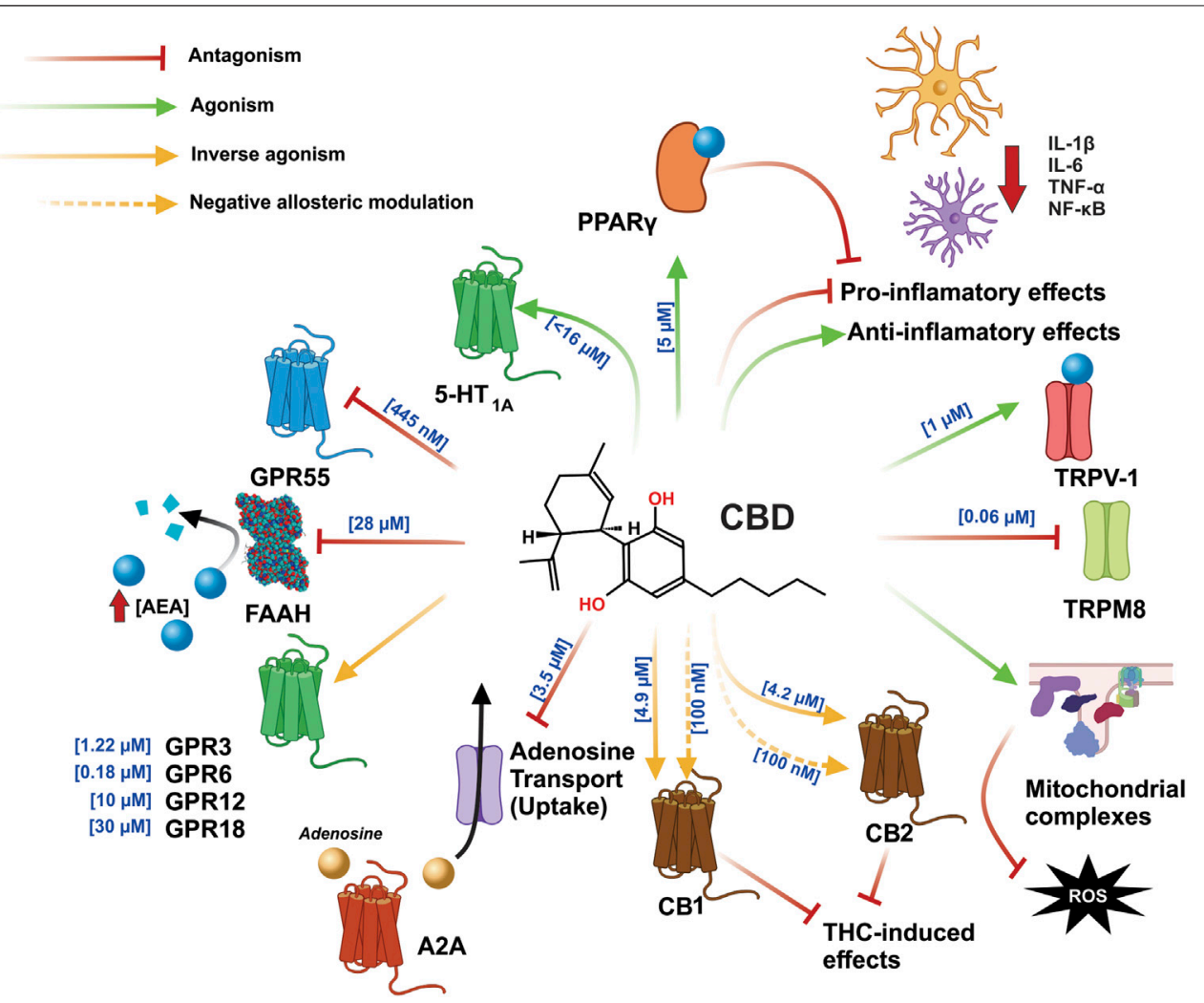

FIGURE 3 | CBD exerts an agonist-like effect on the PPAR $\gamma$, TRPV1, CB1, and CB2 receptors, by inhibiting the enzyme that degrades AEA and FAAH, leading to increased AEA concentration and greater interaction with said receptors. In addition, CBD inhibits GPR55 and TRPM8 and exerts an effect as an inverse antagonist on the GPR3, GPR6, GPR12, CB1, and CB2 receptors; moreover, in CB1 and CB2, it can function as a negative allosteric modulator, which is involved in blocking the effects of THC. The anti-inflammatory effects of CBD function by directly decreasing the synthesis of pro-inflammatory cytokines and increasing the synthesis of anti-inflammatory cytokines. CBD also reduces inflammation by stimulation PPAR $\gamma$. Part of its antioxidant effects are achieved via the increased activity of mitochondrial complexes I, II, II-III, and IV. Abbreviations: CBD, cannabidiol; PPAR $\gamma$, peroxisome proliferator activated receptor $\gamma$; TRPV1, transient potential receptor V1; CB1, cannabinoid receptor type 1; CB2, cannabinoid receptor type 2; AEA, anandamide; FAAH, fatty acid amide hydrolase; GPR55, G protein coupled receptor 55; TRPM8, transient potential receptor M8; GPR3, G protein coupled receptor 3; GPR6, G protein coupled receptor 6; GPR12, G protein coupled receptor 12; THC, tetrahydrocannabinol.

against the effects of THC, by increasing cAMP levels and decreasing ERK $1 / 2$ activity, thus countering the effects induced by the THC. These data may explain the controversial pharmacology of CBD, namely whether or not it interacts with cannabinoid receptors and results from the binding of the two receptors, $\mathrm{CB} 1$ or $\mathrm{CB} 2$, to allosteric sites (Navarro et al., 2018). In the ECS, CBD can exert an effect as an indirect agonist of the $\mathrm{CB} 1$ receptor by inhibiting both the FAAH enzyme and the AEA transporter (Bisogno et al., 2001; Ligresti et al., 2006; De Petrocellis et al., 2011), which leads to an increase in AEA levels and, consequently, in the activation of the CB1 receptor (Howlett et al., 2010), although it can also interact with CB2, TRPV1, and PPARr (Pertwee and Ross, 2002; Ross, 2003; Bouaboula et al., 2005). The TRPV-1 receptor is a molecular target for the pharmacological effects of CBD (Bisogno et al., 2001), which are highly potent (producing an EC50 of $1 \mu \mathrm{M})(\mathrm{De}$ Petrocellis et al., 2011) and, via TRPV-1, increase Ca2+ levels (producing an EC50 of $0.7 \mu \mathrm{M}$ ) (Ligresti et al., 2006). Moreover, $\mathrm{CBD}$, including its precursor, binds at $[5 \mu \mathrm{M}->11.6 \mu \mathrm{M}]$ and activates PPAR $\gamma$ at $[10-20 \mu \mathrm{M}]$, while cannabidiolic acid
(CBDA) binds at $[7.6 \mu \mathrm{M}]$ and activates PPAR $\gamma$ and is more effective than $\mathrm{CBD}$ in activating PPAR $\gamma$ at concentrations of [10-25 $\mu \mathrm{M}]$ (O'Sullivan et al., 2009; Nadal et al., 2017) (Figure 3).

Notable among the independent mechanisms exerted by CBD in the ECS is the agonist binding of the G protein coupled receptors (GPCR) GPR3, GPR6, GPR12, and GPR18, which are considered orphan receptors (Morales and Reggio, 2017). However, lysophosphatidylinositol is considered an endogenous receptor for GPR55 (Alhouayek et al., 2018). CBD exhibits a decrease in concentration-dependent $\beta$-arrestin two recruitment to both GPR3 and GPR6, but with greater potency for the latter (EC50 values of 1.22 and $0.18 \mu \mathrm{M}$, respectively) (Laun and Song, 2017). Furthermore, CBD significantly decreases the cAMP accumulation stimulated by GPR12, in a concentrationdependent manner, corresponding to an approximate EC50 of $10 \mu \mathrm{M}$ (Brown et al., 2017). Therefore, these findings show the inverse agonist effect of the GPR3, GPR6, and GPR12 receptors. $\mathrm{CBD}$ is reported to present a low level of efficacy as an agonist in the recruitment, via GPR18, of $\beta$-arrestin at a concentration of 
$30 \mu \mathrm{M}$ (Console-Bram et al., 2014). However, CBD acts as an antagonist of the effects, induced by $\mathrm{N}$-arachidonoyl glycine (NAGly) and THC, on the migration and morphology of microglia (McHugh et al., 2014). It is likely that the functionality of CBD as an agonist and antagonist depends on the expression of the GPR18 receptor and that CBD may also act as a biased agonist in this GPCR (Morales et al., 2020). It should be noted that, based on the inverse agonist effect that CBD has been shown to have on the GPR55 receptor, novel therapeutic strategies are proposed for treating neurodegenerative diseases via the probable mechanism of this phytocannabinoid (Ryberg et al., 2007; Kaplan et al., 2017). The GPR55 receptor is coupled to the Ga12/13 and Gaq proteins, while its activation promotes the release of $\mathrm{Ca}^{2+}$ stores from the endoplasmic reticulum and, in turn, the activation of MAPKs (Alhouayek et al., 2018). On the other hand, antagonism inhibits $\mathrm{Ca}^{2+}$ currents and causes neuronal inhibition at a presynaptic level. CBD is likely to promote both neuronal repolarization via GPR55, at a presynaptic level, and neuromodulation (Morano et al., 2020). Interestingly, as GPR55 is expressed in a similar way to the CB1 receptors, they are also expressed in the BG circuit (Celorrio et al., 2017).

In addition to the foregoing findings, evidence reported on the mechanism via which $\mathrm{CBD}$ affects the CNS has shown that CBD activates the serotonin receptor 5-HT1A (Russo et al., 2005) and the adenosine A2A receptors (Mecha et al., 2013). CBD behaves as an antagonist with TRPM8 (De Petrocellis et al., 2011), while, acting alone, it has also been found to stimulate the activity of mitochondrial complexes (Valvassori et al., 2013), in addition to, directly and indirectly, stopping the pro-inflammatory process and promoting the anti-inflammatory process, via PPARY (Esposito et al., 2011; Malfait et al., 2000) (Figure 3). It should be noted that the CB1 receptor, TRPV-1, GPR55, and the $\mathrm{A} 2 \mathrm{~A}$ receptor are all abundantly expressed in the $\mathrm{BG}$, which are main structures that participate in the control of movement (Fernández-Ruiz et al., 2010a; Hickey and Stacy, 2012; ChavesKirsten et al., 2013; Celorrio et al., 2017).

\section{THE BASAL GANGLIA IN PARKINSON'S DISEASE AND THE NEUROMODULATORY ROLE OF CANNABIDIOL}

The BG are subcortical nuclei that constitute a parallel and partially closed circuit and are brain structures essential for promoting the initiation and execution of voluntary movements (Lanciego et al., 2012; Klaus et al., 2019). The following nuclei make up the motor circuit of the BG: the caudate-putamen $(\mathrm{CPu})$, which is known as the striatum in rodents and is the main entry nucleus of the BG; the internal and external globus pallidus (GPi and GPe, respectively); the subthalamic nucleus (STN); and, the substantia nigra pars reticulata and substantia nigra pars compacta (SNpr and $\mathrm{SNpc}$, respectively). The main exit nuclei of the $\mathrm{BG}$ are the GPi and SNpr (Albin et al., 1989; Lanciego et al., 2012). The neural information that enters the circuit mainly arrives from the sensorimotor cortex and then circulates through the BG and the thalamus, finally returning to the cerebral cortex. (Alexander and Crutcher, 1990; Haber and Calzavara, 2009). This loop plays an important role in guiding motor behavior; however, the release of dopamine from SNpc neurons in the entry nucleus of the BG is necessary for the motor circuit to properly function (Gerfen and Surmeier, 2011). Various movement disorders emerge from neurochemical dysfunction in the $\mathrm{CPu}$, with dopamine deficiency and the loss of dopaminergic neurons comprising the main characteristics of PD (Figure 4).

Parkinson's disease is a chronic and progressive neurodegenerative condition that manifests in people with characteristic clinical symptoms, such as tremor at rest, bradykinesia, muscle stiffness, and postural instability (Clarke, 2007). Parkinson's disease is the second most common neurodegenerative disease in the world, manifesting in people over 60 years of age (Mhyre et al., 2012), with a global prevalence of 5-35 cases per 100,000 people (Savica et al., 2017). Since the discovery of the decrease in dopamine in the striatum of patients with PD in the 1960s (Hornykiewicz, 1962), the treatment of choice for the disease has been the administration of L-DOPA (Carlsson et al., 1957; Birkmayer and Hornykiewicz, 1961; Bogetofte et al., 2020). However, the chronic administration of L-DOPA in parkinsonian patients shows choreatetotic-type motor complications, called L-DOPA-induced dyskinesia (LID). (Tran et al., 2018). As it has been proposed that this movement disorder, is more disabling than the disease itself, pharmacological proposals for reducing LIDs, such as the use of $\mathrm{CBD}$, could improve quality of life for the parkinsonian patient.

With neurochemical and therapeutic findings showing that dopamine is a key regulatory neurotransmitter in the motor circuit of the BG, the activation of the dopaminergic system is generally associated with increased movement, while its inhibition is associated with hypokinesis (Fernández-Ruiz et al., 2010a). Dopaminergic deficit in the striatum is associated with morphological changes across all BG, a decrease in the number of dendritic spines of the medium spiny neurons (MSNs) in the striatum, and alterations in the neuronal connectivity of the striatopallidal pathway (an indirect pathway) and the striatum-nigral pathway (a direct pathway) (Galvan, et al., 2015).

Due to the fact that the $\mathrm{CB1}$ receptor is found at the presynaptic level, its activation promotes neuromodulatory action via retrograde eCB signaling, mainly in the synapses located in those brain structures that regulate the motor process, namely the corticostriatal pathway and the direct and indirect pathways of the BG (Covey et al., 2017). This action is significant for the functioning of the excitatory and glutamatergic neurons which carry neuronal information through the cortex to the $\mathrm{CPu}$, while the neurons that carry information from the $\mathrm{CPu}$ to the output nuclei are inhibitory and GABAergic in nature (DeLong, 1990). The neurotransmitter dopamine is closely related to the action performed by cannabinoids (FernándezRuiz et al., 2010a; Covey et al., 2017). The CB1 receptor has been considered to be the main receptor involved in controlling the synaptic activity of the dopaminergic neurons of the nigro-striatal pathway, although these neurons do not express CB1 as well as other subpopulations of dopaminergic neurons, such as the 


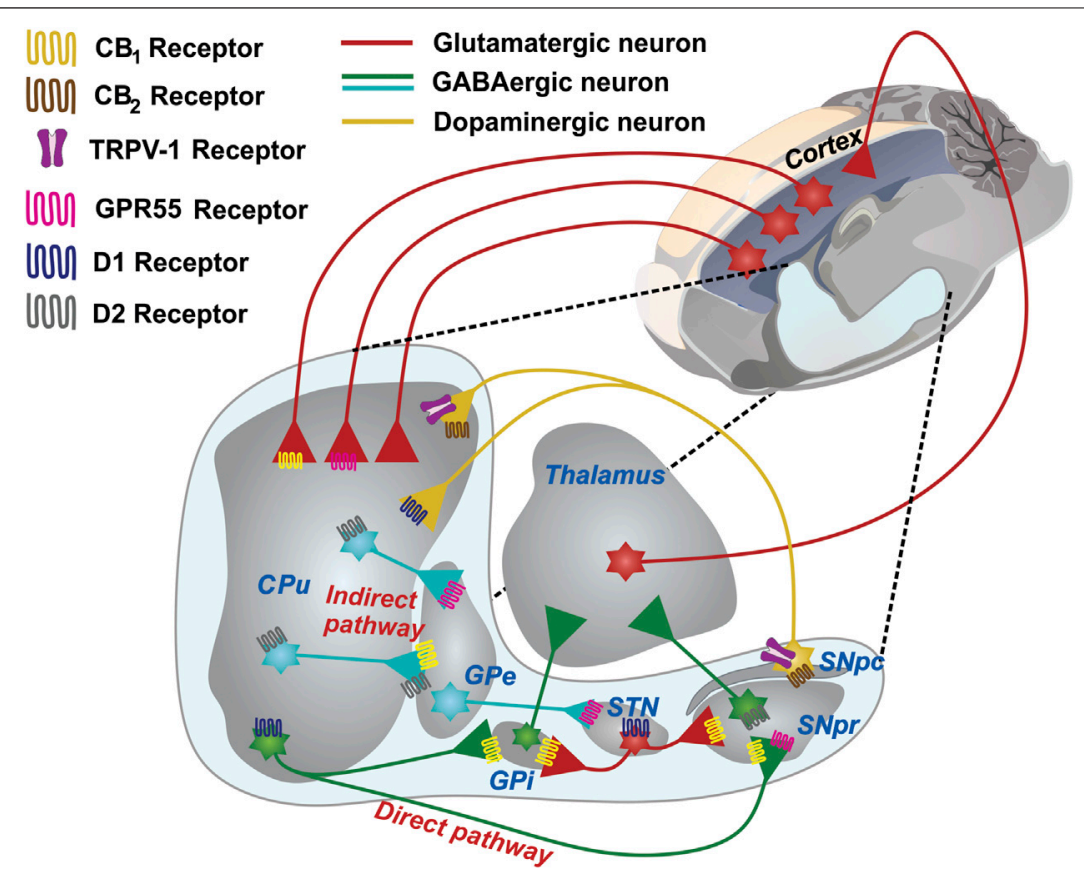

FIGURE 4 | The basal ganglia network and its wide expression of receptors in presynaptic neurons. A schematic representing the GABAergic and glutamatergic connections in a sagittal section of the rat brain is shown. The CPu, the main input nucleus of the circuit, receives cortical projections of glutamatergic neurons. The expression of D1 receptors in the striatum forms the direct pathway of the BG circuit, which is projected toward the GPi and SNpr. The expression of the D2 receptors forms the indirect pathway, which is projected toward the GPe and subsequently toward the STN, which then sends projections to the GPi and SNpr. The projections that emerge from the exit nuclei direct the thalamus and return the processed information to the cerebral cortex. The expression of CB1 receptors mostly occurs in both GABAergic and glutamatergic neurons. GPR55 is present in the GPe, CPu, STN, and SNpc. CB2 and TRPV-1 are the sole in terminals of the SNpc. Abbreviations: CPu, Striatum or caudate-putamen; GPi, Internal globus pallidus; SNpr, Substantia nigra pars reticulata; SNpc, Substantia nigra pars compacta; GPe, External globus pallidus; STN, subthalamic nucleus.

mesostriatal pathway and the cortico-limbic system (García et al., 2016). However, the expression of the CB2 receptor has recently been reported in the dopaminergic neurons of the ventral tegmental area, an important neuronal area that modulates reward (Liu et al., 2017). In human brains, the expression of CB2 in the nigro-striatal pathway (García et al., 2015) has been demonstrated and has even been shown to be associated with pathological conditions (Cassano et al., 2017). The specific deletion of CB2 from the dopaminergic neurons of DAT-Cnr2 conditional knockout (cKO) mice has shown that $\mathrm{CB} 2$ may play an important role in modulating psychomotor behaviors, anxiety, and depression, as well as the rewarding effects of alcohol and cocaine. Furthermore, human genome-wide association studies have shown that the Cnr2 gene is associated with $\mathrm{PD}$ and substance abuse disorders (Liu et al., 2017). Therefore, the regulation that the $\mathrm{CB} 2$ receptor may exert on dopaminergic neurons and that which the $\mathrm{CB} 1$ receptor may exert on the GABAergic neurons of the striatum, GPi, and SNpr could be crucial for neuroprotective and neuromodulatory cannabinoid therapy using CBD (Figure 4).

The effects observed when the $\mathrm{CB} 1$ receptor is activated or blocked in the BG circuit are caused by its action on other neuronal populations, such as the GABAergic (da Silva et al., 2015), glutamatergic (Ren et al., 2009), or opiodergic populations (Prud'homme et al., 2015), which comprise neurons interconnected with the dopaminergic neurons (Stampanoni Bassi et al., 2017). However, it should be noted that anandamide (AEA), N-arachidonoyl-dopamine (NADA), and the synthetic compound AM404 interact and activate the TRPV1 receptor, which is expressed in the nigro-striatal pathway, thus enabling the direct activation of $\mathrm{eCB}$ in the dopaminergic system (Mezey et al., 2000; Cristino et al., 2006) (Figure 4). The CB1 receptors are capable of forming heterodimers with the D2 receptors in striatal projection neurons, enabling both systems to interact directly in postsynapse (Blume et al., 2013). Therefore, the range of receptors found in the striatum may be involved in the modulation, via eCB and cannabinoids such as $\mathrm{CBD}$, that is proposed in the present study.

A study conducted on intact rat striatal synaptosomes identified various modulatory mechanisms that cannabinoids may execute on the reuptake of dopamine, glutamate, and adenosine (Pandolfo et al., 2011). Specifically, CBD has shown a low capacity for inhibiting dopamine reuptake (IC50 = $16.5 \mu \mathrm{M})$, a finding similar to that reported by Poddar and Dewey 1980, who found that, in striatum synaptosomes, high concentrations of CBD were needed to produce an inhibitory effect on dopamine recapture. This finding is important for understanding the modulatory role of CBD in PD, as $90 \%$ of dopaminergic neuronal death occurs in PD (Cheng et al., 2010), 
meaning that CBD treatment in the latter stages of the disease is likely to be ineffective. Furthermore, CBD had potent inhibitory effects on adenosine reuptake (IC50 $=3.5 \mu \mathrm{M}$ ) (Pandolfo et al., 2011), which may explain its neuromodulatory activity via the expression of the A2A receptors in the BG circuit (Schiffmann et al., 2007). The A2A receptor has been shown to be widely expressed in the striatopallidal pathway, in presynaptic and postsynaptic GABAergic neurons (Rosin et al., 2003; Diao et al., 2017). Moreover, as the function of the A2A receptor is to inhibit the release of GABA, it will promote movement in an animal PD model (Schwarzschild et al., 2006). However, it is likely that interactions with various neurotransmitter receptors can activate, in addition to neuronal modulation, neuronal signaling pathways that promote neuronal survival. To address the probable neuroprotective effect of $\mathrm{CBD}$, it is necessary to identify the proposed pharmacological approaches that harness the medicinal properties of phytocannabinoids as an adjuvant in PD treatment.

\section{CANNABIDIOL AS AN ADJUVANT IN PARKINSON'S DISEASE TREATMENT}

Various studies have suggested that both genetic (5-10\%) and idiopathic factors may contribute to the neurodegeneration that occurs in $p \mathrm{D}$. However, the etiology of this disease, namely the underlying cause of dopaminergic neuronal death, is unknown (Kalinderi et al., 2016; Deng et al., 2018). Several studies have linked the idiopathic factors in PD to both aging and environmental factors (heavy metals, pesticides, head trauma, and viral infections) (Ascherio and Schwarzschild, 2016; Pang et al., 2019). Two processes, oxidative stress and neuroinflammation, are closely related to both the genetic and idiopathic factors observed in PD (Hald and Lotharius, 2005). There is evidence that the dopaminergic neurons of the SNpc are vulnerable to oxidative damage, as they present low levels of antioxidant enzymes, such as glutathione peroxidase, and high levels of pro-oxidants, such as free iron and neuromelanin (González-Hernández et al., 2010). The oxidative characteristics of the SNpc promote increased ROS levels, induce the inhibition of the mitochondrial electron transport chain, increase glutamate levels, stimulate NMDA receptors, and, finally, induce the processes of excitotoxicity and neuronal death (Hernandez-Baltazar et al., 2019). Indeed, one of the aims of neuroprotective therapeutic strategies for PD is to reduce the cytotoxic effects of oxidative stress, namely lipid peroxidation, protein nitration, and DNA oxidation, a point reviewed in the next section.

In addition to the role played by the neuronal population, the participation of glial cells (astrocytes and microglia) is essential for the development of PD (Hernandez-Baltazar et al., 2019; Domingues et al., 2020). Glial cells are associated with neuroinflammation and the neurodegenerative process, with the former characterized by reactive microglia and the presence of astrocytes alongside neurons with dopaminergic injury (Bachiller et al., 2018). Microglia are considered the resident innate immune cells and are, therefore, capable of robust chemotaxis, phagocytosis, and cytokine production and release (Domingues et al., 2020). It should be noted that recent studies have phenotypically categorized microglia cells into M1 (pro-inflammatory) and M2 (anti-inflammatory) states (Tang and Le, 2016) (Figure 5). In the M2 state, microglia improve neuronal survival by releasing glial cell line-derived neurotrophic factor (GDNF) (Ding et al., 2004) and are involved in the upregulation of tissue repair and gene regeneration (Le et al., 2016). In contrast, in the M1 state, microglia promote the neurodegeneration of the nigrostriatal pathway in $p \mathrm{D}$. Microglia produce and increase ROS levels in a proinflammatory state, thus producing IL-1 $\beta, \mathrm{IL}-6, \mathrm{TNF} \alpha$, chemokines, $\mathrm{NO}^{\text {? }}$, and $\mathrm{O}_{2}{ }^{--}$(Liu and Hong, 2003; Subramaniam and Federoff, 2017). This release of proinflammatory cytokines activates signaling pathways in order to promote microglia recruitment and, thus, dopaminergic cell death (Hernandez-Baltazar et al., 2019).

Astrocytes, the class of glial cells that are most present in the mammalian CNS, are metabolic, supportive of neuronal structure, and release neurotrophic factors. Furthermore, they maintain the integrity of the $\mathrm{BBB}$ and modulate neuronal transmission and excitability (Domingues et al., 2020). Following dopaminergic neuronal injury, mature astrocytes proliferate and promote neuronal regeneration via brainderived neurotrophic factor (BDNF) and cerebral dopamine neurotrophic factor (CDNF) (Hernandez-Baltazar et al., 2019). Astrocytes detect cellular insult signals and trigger an immune response through the secretion of cytokines and chemokines. However, an imbalance in the secretion of pro-inflammatory/ anti-inflammatory substances contributes to neuroinflammation and chronic neurodegeneration (Colombo and Farina, 2016; Liddelow et al., 2017). For this reason, one of the novel and opportune treatment strategies for $\mathrm{PD}$ is to modulate the neuroinflammation occurring during the progression of the disease.

Interestingly, while both the $\mathrm{CB} 1$ and $\mathrm{CB} 2$ receptors are expressed in astrocytes, the $\mathrm{CB} 2$ receptor is overexpressed under neuroinflammatory conditions in both the microglia and astrocytes (Benito et al., 2005; Cassano et al., 2017). Although the main receptor involved in the modulation of reactive glia is the $\mathrm{CB} 2$ receptor, a neuroprotective effect of the $\mathrm{CB1}$ receptor that directly involves the glia cannot be ruled out (Chung et al., 2011). The modulating effects of astrocytic activity with brain injury is mediated by cannabinoids via the $\mathrm{CB} 2$ receptor, or the $\mathrm{CB} 1$ and $\mathrm{CB} 2$ receptors combined (Fernández-Ruiz et al., 2010a; Stella, 2010) (Figure 5). These effects promote a trophic role or provide antiinflammatory mediators that can rescue damaged neurons (IL10 , TGF- $\beta$ ) and promote the reduction of chemokine levels by astrocytes such as fractalkine, an effect that would be predominantly mediated by the activation of $\mathrm{CB} 2$ receptors (Smith et al., 2000; Molina-Holgado et al., 2003). Particularly when activated, microglia are affected by the activation of $\mathrm{CB} 2$ receptors in the $\mathrm{CNS}$, while the $\mathrm{CB} 2$ receptors also play a role in the proliferation and migration of these cells at injury sites (Walter et al., 2003; Carrier et al., 2004). The activation of CB2 receptors in microglia dampens the generation of 

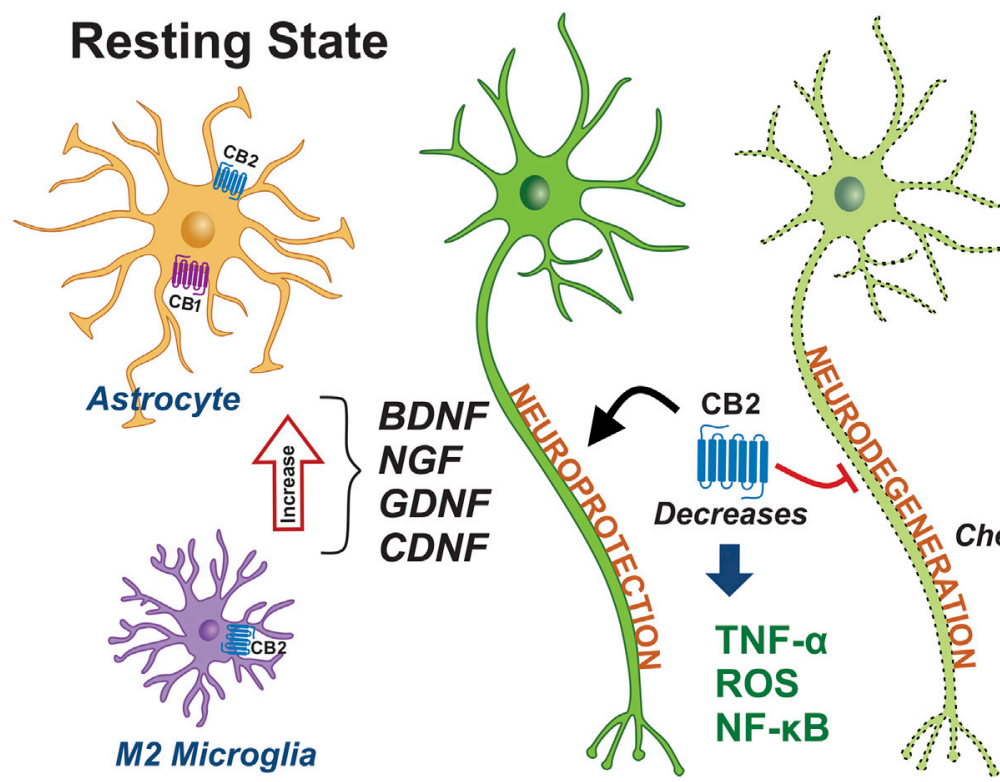

\section{Activated State}
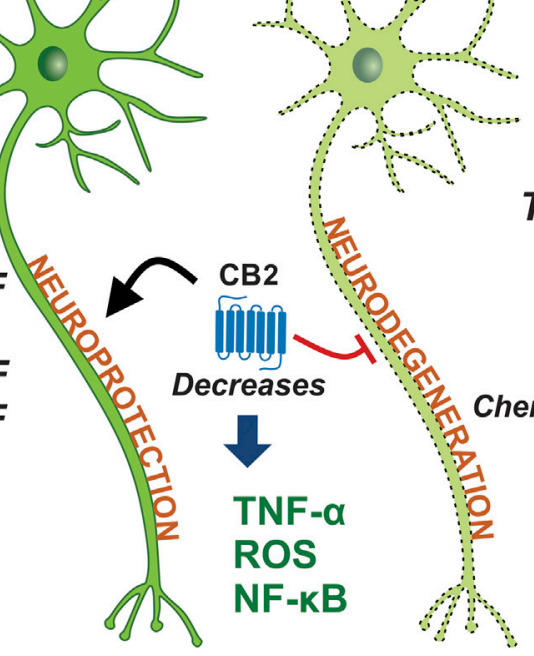

\section{TNF-1}
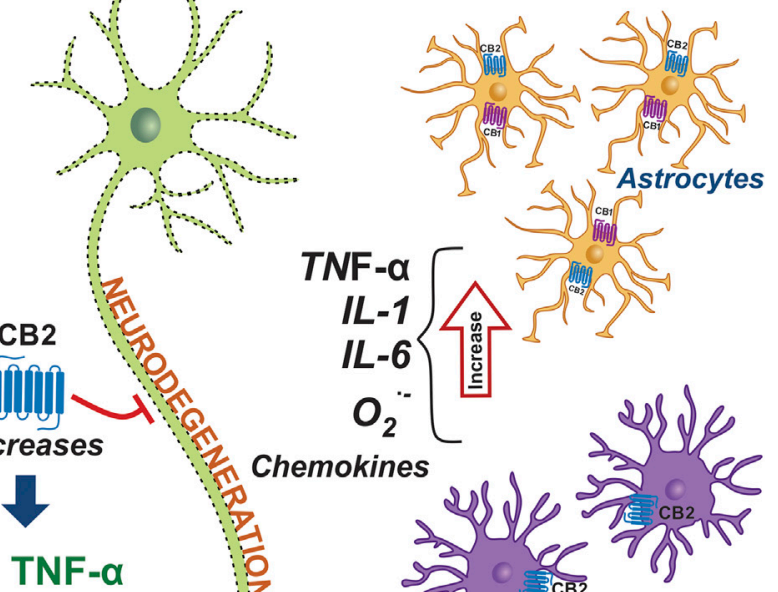

ROS

NF-KB

FIGURE 5 | Expression of cannabinoid receptors in glial cells and their role in PD. The phenotypes of microglia and astrocytes are schematically represented under non-inflammatory conditions, namely in a resting state. The microglia and astrocytes are shown in pro-inflammatory conditions and in an active state. The activation of microglia and astrocytes promotes and triggers the neuroinflammation that contributes to PD. The activation of the CB1 and CB2 receptors may decrease the inflammation seen in PD. Abbreviations: CB1, cannabinoid receptor type 1; CB2, cannabinoid receptor type 2; BDNF, brain-derived neurotrophic factor; NGF, nerve growth factor; GDNF, glial cell line-derived neurotrophic factor; CDNF, cerebral dopamine neurotrophic factor; ROS, reactive oxygen species; NF-kB, nuclear factor kappa B; IL-1, interleukin-1; IL-6, interleukin-1; $\mathrm{O}_{2}{ }^{-}$, Superoxide anion; TNF-a, tumor necrosis factor alpha.

neurotoxic factors such as TNF-a (Stella, 2010) and the transcription factor $\mathrm{NF}-\kappa \mathrm{B}$, which regulates pro-inflammatory responses (Oh et al., 2010). Therefore, the expression of the CB2 receptor in both reactive microglia and astrocytes suggests that it could be a target for promoting neuroprotection (Fernández-Ruiz et al., 2015). It is likely that CBD is able to regulate the CB1 and $\mathrm{CB} 2$ receptors in both the glial cells and the BG circuit, via noncanonical mechanisms.

Currently, orthodox L-DOPA therapy reduces the symptoms of PD; however, there are no therapies that can prevent or rescue neurons from death (Choonara et al., 2009; Schapira et al., 2014). In these circumstances, L-DOPA is no longer metabolized by dopaminergic neurons, due to the degeneration of between 50 and $70 \%$ of nigral DA neurons (Carta and Bezard, 2011). Serotonergic neurons possess the enzymatic machinery for synthesizing dopamine via L-DOPA, promoting vesicular storage, and expressing the vesicular monoamine transporter (VMAT). However, serotonergic neurons lack a regulatory mechanism for dopamine release and regulation, a function which is carried out by the presynaptic D2 receptor and, therefore, induces the excessive release of dopamine into the $\mathrm{CPu}$ (Arai et al., 1995). As the disease progresses and dopaminergic neuronal death increases, the efficiency of L-DOPA decreases and patients experience the abnormal involuntary movements known as LIDs (Putterman et al., 2007; Francardo et al., 2011). For this reason, it is necessary to develop new non-dopaminergic drugs capable of reducing or attenuating motor symptoms without inducing dyskinesias, with the use of cannabinoids an interesting therapeutic approach to $\mathrm{PD}$, one which has emerged alongside a new class of drugs. Cannabidiol has no psychoactive effects and has shown encouraging results in preclinical and clinical trials conducted on different neurodegenerative diseases. It is also a multi-target drug, as, in addition to acting on the ECS, it can act on the serotonin, adenosine, dopamine, and opioid receptors (Russo et al., 2005; Carrier et al., 2006; Kathmann et al., 2006; Thomas et al., 2007; Pandolfo et al., 2011; Linge et al., 2016; Sonego et al., 2018). As most of the aforementioned CBD-activated receptors are coupled to an inhibitory $\mathrm{G}$ protein, they are capable of acting as neuromodulators, given that they regulate the release of other neurotransmitters.

Clinical trials evaluating the effects of cannabinoids on PD show conflicting results. Nabilone (a non-selective $\mathrm{CB} 1$ receptor and CB2 receptor agonist) decreases L-DOPA-induced dyskinesias. It has been suggested that the lateral globus pallidus ( $\mathrm{GPl}$ ) exbibits hyperactive behavior in the dyskinetic process and that the stimulation of CBRs improves GABAergic transmission by reducing GABA reuptake in the GPl (Sieradzan et al., 2001). The oral administration of a cannabis extract in PD patients was well tolerated but did not produce an antiparkinsonian effect (Carroll et al., 2004), while the administration of cannabis has been shown to have a beneficial effect on tremor and stiffness, a minor effect on bradykinesia, and a tendency to improve posture, all of which are motor symptoms of $p \mathrm{D}$. Cannabis been found to have a positive impact on non-motor symptoms, such as sleep and pain 
(Lotan et al., 2014), with the latter finding potentially attributable, in part, to nighttime pain relief and, in part, to the drug's calming and soporific effects. Some studies have found cannabis-induced improvements in sleep quality rather than motor symptoms (Finseth et al., 2015). While a single smoked dose of marijuana has not been found to decrease tremor in PD patients, its sedative or anxiolytic effect benefits some patients when anxiety is a significant trigger (Frankel et al., 1990). The different results obtained by these studies are related to variations in the amount of plant extract administered and the different routes of administration, where, for example, oral administration produces lower plasma concentrations than inhalation.

A double-blind, placebo-controlled, cross-sectional study evaluated the severity and duration of LIDs and the effect on these symptoms of the administration of a cannabis extract (Cannador ${ }^{\circledR}$ ), comprising $\mathrm{THC} / \mathrm{CBD}$, to eighteen patients, in doses of up to $0.5 \mathrm{mg} / \mathrm{kg} /$ day. The results obtained did not show any significant difference, although some patients did report reduced tremor and improved sleep quality compared to those who had received the placebo, as well as an improved dementia score via the Mini-Mental State Examination (MMSE) (Carroll et al., 2004). Some of the first clinical studies in this area were driven by testimonies, such as the anecdotal account of a patient with severe Parkinson's tremor who had been resistant to different types of medication until experiencing dramatic relief from smoking marijuana. This prompted a study to be conducted on five idiopathic PD patients, who were evaluated via the Webster scale and revealed improvements in tremor after the administration of smoked marijuana ( $1 \mathrm{~g} \approx 29 \mathrm{mg}$ of THC), L-DOPA, and apomorphine. These authors found no evidence to show that smoking cannabis reduces tremor or other parkinsonian symptoms (Frankel et al., 1990). Another evaluation of smoked cannabis was undertaken in an open study, in which, of the 22 patients who received ultimately ineffective treatments to relieve pain and tremor for ten months, seven experienced motor fluctuations. Moreover, an improvement in motor symptoms was obtained, with a greater benefit observed in tremor and bradykinesia, while, in addition to improved posture, improvements in non-motor symptoms and good tolerability were also found (Lotan et al., 2014).

Recent studies have highlighted the synergistic effect among the components of cannabis (Samarut et al., 2019), especially those with the highest concentrations, namely THC and CBD (Jin et al., 2020). This effect may generate limitations, as it is difficult to determine the mechanism by which results were obtained, although cannabis also has advantages over other treatments due to its benefits in terms of various therapeutic objectives, mainly achieved via the use of CBD (Morales et al., 2017; Peres et al., 2018). As the improvement of parkinsonian symptoms was observed to be related to the use of cannabis for more than two months (Venderová et al., 2004), the time period in which the treatment is applied is an important factor. More studies are required in order to evaluate the effect of cannabinoids on LIDs, considering the duration, the dosing, and the use of routes of administration that do not cause secondary damage (Varlet et al., 2016; Millar et al., 2018).

\section{CANNABIDIOL AS A DRUG WITH PROBABLE NEUROPROTECTIVE PROPERTIES}

The first reports of clinical research on the treatment of PD with CBD were followed by the studies carried out by Snider and Consroe (1985) and Consroe et al. (1986). They showed that, in two patients with dystonia and coexisting Parkinsonian characteristics, oral CBD treatment at doses higher than $300 \mathrm{mg} /$ day exacerbated hypokinesia and tremor at rest, and had a positive effect on dystonic movements (Snider and Consroe, 1985). Consroe showed CBD to be effective in treating LIDs in PD patients, a finding that was perhaps the first to show the beneficial effect of CBD on LIDs (Consroe et al., 1986); however, given that he did not report the beneficial effects of $\mathrm{CBD}$ on $\mathrm{PD}$, it is likely that interest in the potential of CBD as a treatment for this condition dwindled. It was not until the 2000s that $\mathrm{CBD}$ regained relevance in $\mathrm{PD}$ research, as a result of a study conducted on healthy recreational users of both marijuana (plant) and resin (hashish). The study analyzed subjects' hair samples for both THC and CBD levels (as determined by chromatography/ mass spectrometry), finding an increase in the levels of the markers of the cerebral metabolism of $\mathrm{N}$ - Acetylaspartate (NAA)/Total Creatinine ( $\mathrm{tCr}$ ) in the putamen/globus pallidus, as determined by magnetic resonance spectroscopic imaging (MRSI). A positive correlation between $\mathrm{NAA} / \mathrm{tCr}$ and $\mathrm{CBD}$ was also observed in the striatopallidal pathway (Hermann et al., 2007), a finding which may reflect a possible improvement in the neuronal and axonal integrity of the indirect BG pathway due to the effects of CBD. In addition, this finding led to the proposal of $\mathrm{CBD}$ as a therapeutic target during the initiation of $\mathrm{PD}$, given that $\mathrm{GPe}$ is the nucleus with the highest expression of the $\mathrm{CB} 1$ receptor and is the nucleus with the highest level of GABAergic activity, thus promoting hypokinesia.

Studies on the administration of CBD have been undertaken on patients with non-motor PD symptoms (Table 1). In 2009, Zuardi carried out a study on six patients presenting both psychosis and the motor symptoms of $p \mathrm{D}$. The four-week treatment regime began with a $150 \mathrm{mg}$ dose, which, depending on the clinical response, was increased by $150 \mathrm{mg}$ each week. All evaluations were performed via tests and clinical evaluation scales for anxiety and cognition, with CBD observed to decrease PD psychosis, while no difference was observed in motor processes (Zuardi et al., 2009). The same author conducted two parallel studies evaluating PD motor disorders and REM sleep behavior disorder (RBD). The effect of the CBD treatment on RBD was evaluated in a group of four patients with symptoms characteristic of $\mathrm{PD}$ and the sleep disorders caused by the disease. The CBD dose was $75 \mathrm{mg} /$ day and $300 \mathrm{mg}$ /day per patient, with both treatments lasting six weeks. The polysomnograph evaluation conducted revealed that the CBD attenuated RBD (Chagas et al., 2014a).

In order to explore the role of CBD in the motor symptoms of $\mathrm{PD}$, a study was conducted with $21 \mathrm{PD}$ patients who had recorded a score of one to three on the Hoehn and Yahr scale, using a CBD dose of $75 \mathrm{mg} /$ day or $300 \mathrm{mg} /$ day for three weeks. While an increase in general well-being and functioning in daily tasks was 
TABLE 1 | Clinical research reports on the effect of CBD on Patients of PD.

\begin{tabular}{|c|c|c|c|c|c|}
\hline $\begin{array}{l}\text { Patient } \\
\text { characteristics }\end{array}$ & Symptoms & $\begin{array}{l}\text { CBD dosage } \\
\text { and temporary } \\
\text { treatment }\end{array}$ & $\begin{array}{l}\text { Medical evaluations } \\
\text { and study } \\
\text { techniques }\end{array}$ & Main findings & $\begin{array}{c}\text { Author } \\
\text { (reference) }\end{array}$ \\
\hline $\begin{array}{l}13 \text { male recreational cannabis } \\
\text { users (six users consumed } \\
\text { marijuana, three hashish and } \\
\text { four marijuana and hashish). } \\
\text { Mean age } 22 \text { years, } \\
\text { approximately }\end{array}$ & $\begin{array}{l}\text { All participants were } \\
\text { medication free. They had } \\
\text { not brain disorders and other } \\
\text { diseases }\end{array}$ & $\begin{array}{l}6 \text { years of using marijuana or } \\
\text { hashish }\end{array}$ & $\begin{array}{l}\text { Chromatography/mass } \\
\text { spectrometry (GC/MS) to hair } \\
\text { analysis of cannabinoids (THC } \\
\text { and } \mathrm{CBD})^{1} \mathrm{H} \text { magnetic } \\
\text { resonance spectroscopic } \\
\text { imaging (MRSI) markers of brain } \\
\text { metabolism: NAA, cho and } \mathrm{tCr}\end{array}$ & $\begin{array}{l}\uparrow \text { positive correlation of } \\
\text { NNA/tCr and CBD in the } \\
\text { putamen/globus pallidus }\end{array}$ & $\begin{array}{l}\text { Hermann } \\
\text { et al. (2007) }\end{array}$ \\
\hline $\begin{array}{l}\text { Six patients (four men and two } \\
\text { women). Mean age } 58 \text { years, } \\
\text { approximately }\end{array}$ & $\begin{array}{l}\text { Patients had psychosis for } \\
3 \text { months and motor } \\
\text { sympotms of PD }\end{array}$ & $\begin{array}{l}150 \text { mg CBD (p.o.), and } \\
\text { increasing } 150 \text { mg every } \\
\text { week depending on the } \\
\text { clinical response. Four } \\
\text { weeks of treatment }\end{array}$ & $\begin{array}{l}\text { Bech's version of the brief } \\
\text { psychiatric rating scale (BPRS) } \\
\text { structured interview guide with } \\
\text { test-retest reliability of the BPRS } \\
\text { Parkinson psychosis } \\
\text { questionnaire (PPQ) unified } \\
\text { Parkinson's disease rating scale } \\
\text { (UPDRS) clinical global } \\
\text { impression - Improvement scale } \\
\text { (CGI-I) Mini-Mental State } \\
\text { Examination (MMSE) frontal } \\
\text { assessment battery (FAB) }\end{array}$ & $\begin{array}{l}\downarrow \text { psychotic symptoms in } \\
\text { PD CBD did not worsen } \\
\text { the motor function CBD } \\
\text { did not induce any } \\
\text { decrease in cognitive } \\
\text { function }\end{array}$ & $\begin{array}{l}\text { Zuardi et al. } \\
\text { (2009) }\end{array}$ \\
\hline $\begin{array}{l}\text { Four male PD patients with } \\
\text { RBD. Mean age } 63 \text { years, } \\
\text { approximately }\end{array}$ & $\begin{array}{l}\text { Alterations during sleep } \\
\text { characterized by swearing, } \\
\text { talking, yelling, pushing, } \\
\text { kicking, punching and } \\
\text { gesturing and motor } \\
\text { sympotms of PD }\end{array}$ & $\begin{array}{l}75 \mathrm{mg} / \text { day CBD (p.o.) in } \\
\text { three patients } 300 \mathrm{mg} / \text { day } \\
\text { CBD (p.o.) in one patient } \\
\text { duration of treatment, six } \\
\text { weeks }\end{array}$ & $\begin{array}{l}\text { Polysomnography (PSG) } \\
\text { periodic limb movement index } \\
\text { (PLMI) }\end{array}$ & $\begin{array}{l}\downarrow \text { frequency of RBD- } \\
\text { related events }\end{array}$ & $\begin{array}{l}\text { Chagas et al. } \\
(2014 a)\end{array}$ \\
\hline $\begin{array}{l}21 \text { ( } 15 \text { male and } 6 \text { female) PD } \\
\text { patients. Mean age } 65 \text { years, } \\
\text { aproximately }\end{array}$ & $\begin{array}{l}\text { Motor symptoms of } \\
\text { idiopathic PD, score } \\
\text { between } 1 \text { and } 3 \text { in the } \\
\text { hoehn and yahr scale }\end{array}$ & $\begin{array}{l}75 \mathrm{mg} / \text { day or } 300 \mathrm{mg} / \text { day } \\
\text { CBD (p.o.) duration of } \\
\text { treatment, six weeks }\end{array}$ & $\begin{array}{l}\text { UPDRS to assess PD symptoms } \\
\text { Parkinson'|'s disease } \\
\text { questionnaire - } 39 \text { (PDQ-39) } \\
\text { plasma levels of BDNF (ELISA) } \\
\text { proton magnetic resonance } \\
\text { scans (MRS) }\end{array}$ & $\begin{array}{l}\uparrow \text { functioning and well- } \\
\text { being of PD patients (NC) } \\
\text { motor score evaluated } \\
\text { with the UPDRS (NC) } \\
\text { BDNF plasma levels (NC) } \\
\text { NAACr for MRS }\end{array}$ & $\begin{array}{l}\text { Chagas et al. } \\
(2014 b)\end{array}$ \\
\hline $\begin{array}{l}24 \text { (male and female) idiophatic } \\
\text { PD patients }\end{array}$ & $\begin{array}{l}\text { Motor symptoms of } \\
\text { idiopathic PD, and anxiety an } \\
\text { absence of marked cognitive } \\
\text { alterations }\end{array}$ & $\begin{array}{l}300 \text { mg CBD (p.o.) with } \\
\text { interval between the first and } \\
\text { the second experiment was } \\
15 \text { days (two administration) }\end{array}$ & $\begin{array}{l}\text { UPDRS to assess PD symptoms } \\
\text { hoehn and yahr scale schwab } \\
\text { and england scale simulated } \\
\text { public speaking test (SPST)- } \\
\text { VAMS; SPST; SSPS systemic } \\
\text { blood pressure and heart rate } \\
\text { tapping test accelerometer } \\
\text { (tremors measured) }\end{array}$ & $\begin{array}{l}\downarrow \text { SPST-induced anxiety } \\
\downarrow \text { tremor amplitude in } \\
\text { patients with PD }\end{array}$ & $\begin{array}{l}\text { De Faria } \\
\text { et al., } 2020\end{array}$ \\
\hline
\end{tabular}

$B D N F$, brain-derived neurotrophic factor; CBD, cannabidiol; Cho, choline; ELISA, enzyme-linked immunosorbent assay; NAA, N-acetylaspartate; RBD, REM sleep behavior disorder; SPST, simulated public speaking test; SSPS, self-statements during public speaking scale; tCr, total Creatine; THC, tetrahydrocannabinol; VAMS, visual analog mood scales; ( $\uparrow$ ) increase; (】) decrease; NC, no changes.

observed, alterations were not observed in the motor score evaluated via the Unified Parkinson's disease Rating Scale (UPDRS) or the plasma levels of BDNF and NAA/Cr, as measured via proton magnetic resonance scans (MRI) (Chagas et al., 2014b). The results for effects of CBD on PD in clinical research are likely not as encouraging, suggesting that increased clinical research efforts are required in this area.

Hampson et al. first reported the neuroprotective effects of CBD in 1998, using the primary cultures of cortical neurons exposed to toxic concentrations of the neurotransmitter glutamate $[250 \mu \mathrm{M}]$ for $10 \mathrm{~min}$, finding that $\mathrm{CBD}$ prevented both glutamatergic neurotoxicity, with an EC50 of $2-4 \mu \mathrm{M}$, and cell death induced by oxidative stress. In addition, they observed that the antioxidant effect of $\mathrm{CBD}$ was more powerful than $a$-tocopherol and ascorbate in equimolar concentrations, finding that neuroprotection was not inhibited by CBR antagonism, thus indicating the independent therapeutic effects of CB1 and CB2 (Hampson et al., 1998). The CBRindependent antioxidant effect of $\mathrm{CBD}$ has also been demonstrated in B-lymphobalstoid and fibroblast cell cultures serum-starved for survival (Chen and Buck, 2000). The ability of CBD to attenuate the neurotoxicity induced by two oxidative insults was also observed, finding stress and mitochondrial dysfunction in cultured granular neurons at $2.5 \mu \mathrm{M}$ concentrations due to the effect of both CBR-independent and 5-HT-1A mechanisms (Echeverry et al., 2020). As the antioxidant effect of CBD was observed to play an important role in neuroprotection, it was proposed as a possible therapeutic agent in the treatment of highly oxidative neurodegenerative disorders, such as PD. 
TABLE 2 | Preclinical research reports of effect CBD on various in vivo models of PD.

\begin{tabular}{|c|c|c|c|c|c|c|c|c|c|}
\hline $\begin{array}{l}\text { Animal } \\
\text { species } \\
\text { studied }\end{array}$ & $\begin{array}{l}\text { Lesion } \\
\text { model }\end{array}$ & $\begin{array}{l}\text { Lesion } \\
\text { time }\end{array}$ & CBD dosage & $\begin{array}{l}\text { Treatment } \\
\text { time }\end{array}$ & $\begin{array}{l}\text { Brain } \\
\text { nuclei } \\
\text { studied }\end{array}$ & $\begin{array}{l}\text { Biochemical } \\
\text { markers }\end{array}$ & $\begin{array}{l}\text { Proteins/mRNA } \\
\text { evaluated }\end{array}$ & $\begin{array}{l}\text { Evaluated } \\
\text { animal } \\
\text { behavior }\end{array}$ & $\begin{array}{c}\text { Author } \\
\text { (reference) }\end{array}$ \\
\hline \multirow[t]{2}{*}{$\begin{array}{l}\text { Sprague-Dawley } \\
\text { rat }\end{array}$} & $\begin{array}{l}6-\mathrm{OHDA}[8 \mu \mathrm{g} / 2 \mu \mathrm{l}] \\
\text { in MFB }\end{array}$ & 2 weeks & CBD (3 mg/kg i.p.) & $\begin{array}{l}\text { Two weeks, CBD } \\
\text { administration } 16 \mathrm{~h} \text { post 6- } \\
\text { OHDA }\end{array}$ & Striatum & $\begin{array}{l}\uparrow \text { dopamine (NC) } \\
\text { DOPAC. (NC) TH } \\
\text { activity }\end{array}$ & & Not evaluated & $\begin{array}{l}\text { Lastres-Becker et al. } \\
\text { (2005) }\end{array}$ \\
\hline & & & & & $\mathrm{SNpc}$ & & $\begin{array}{l}\text { (NC) mRNA SP (ISH) } \\
\text { (NC) mRNA PENK } \\
\text { (ISH) (NC) mRNA TH } \\
\text { (ISH) }\end{array}$ & & \\
\hline \multirow[t]{2}{*}{$\begin{array}{l}\text { Sprague-Dawley } \\
\text { rat }\end{array}$} & \multirow[t]{2}{*}{$\begin{array}{l}\text { 6-OHDA [8 } \mu \mathrm{g} / 2 \mu \mathrm{l}] \\
\text { in MFB }\end{array}$} & \multirow[t]{2}{*}{2 weeks } & \multirow[t]{2}{*}{ CBD (3 mg/kg i.p.) } & \multirow{2}{*}{$\begin{array}{l}1 \text { week }(1 \mathrm{~W}), \mathrm{CBD} \\
\text { administration } 7 \text { days' post 6- } \\
\text { OHDA } 2 \text { weeks }(2 \mathrm{~W}) \text {, CBD } \\
\text { administration } 16 \mathrm{~h} \text { post } 6- \\
\text { OHDA }\end{array}$} & Striatum & \multirow[t]{2}{*}{$\begin{array}{l}\uparrow \text { dopamine } 2 \mathrm{~W} \\
\text { (NC) dopamine } 1 \mathrm{~W}\end{array}$} & & \multirow[t]{2}{*}{ Not evaluated } & \multirow[t]{2}{*}{$\begin{array}{l}\text { García-Arencibia } \\
\text { et al. (2007) }\end{array}$} \\
\hline & & & & & $\mathrm{SNpc}$ & & $\begin{array}{l}\uparrow \mathrm{mRNASOD} \mathrm{Cu} / \mathrm{Zn} \\
2 \mathrm{~W}(\mathrm{ISH})(\mathrm{NC}) \\
\mathrm{mRNA} S \mathrm{SOD} \mathrm{Cu} / \mathrm{Zn} \\
1 \mathrm{~W}(\mathrm{ISH})\end{array}$ & & \\
\hline $\begin{array}{l}\text { Sprague-Dawley } \\
\text { rat }\end{array}$ & $\begin{array}{l}6-\mathrm{OHDA}[200 \mu \mathrm{g} / \\
5 \mu \mathrm{l}] \text { i.c.v injection }\end{array}$ & 2 weeks & $\begin{array}{l}\text { CBD enriched } \\
\text { botanical extract } \\
\text { (equivalent to } \\
3 \mathrm{mg} \cdot \mathrm{kg}-1 \text { of pure } \\
\text { CBD i.p.) }\end{array}$ & $\begin{array}{l}2 \text { weeks, CBD administration } \\
16 \mathrm{~h} \text { post } 6-\mathrm{OHDA}\end{array}$ & SNpc & Not evaluated & $\begin{array}{l}\uparrow \mathrm{TH}(\mathrm{IHC}) \downarrow \mathrm{OX}-42 \\
(\mathrm{IHC})\end{array}$ & Not evaluated & García et al. (2011) \\
\hline Wistar rat & $\begin{array}{l}\text { Reserpine (dosage } \\
1 \mathrm{mg} / \mathrm{kg} \text { s.c.) } 2 \text { days } \\
\text { administration }\end{array}$ & 6 days & $\begin{array}{l}\mathrm{CBD}(0.5 \text { and } 5 \mathrm{mg} / \mathrm{kg} \\
\text { i.p.) }\end{array}$ & $\begin{array}{l}7 \text { days, administration one day } \\
\text { before reserpine }\end{array}$ & $\begin{array}{l}\text { Not } \\
\text { evaluated }\end{array}$ & Not evaluated & Not evaluated & $\begin{array}{l}\text { (NC) locomotor activity } \downarrow \text { time } \\
\text { bar test catalepsy } \downarrow \text { vacuous } \\
\text { chewing movements plus-maze } \\
\text { discriminative avoidance task } \\
\text { (attenuate the reserpine- } \\
\text { induced memory deficit) }\end{array}$ & Peres et al. (2016) \\
\hline \multirow[t]{3}{*}{ C57BL/6Mice } & $\begin{array}{l}\text { MPTP (dosage } \\
20 \text { mg/kg i.p.) }\end{array}$ & 5 weeks & CBD (5 mg/kg i.p.) & $\begin{array}{l}5 \text { weeks. Joint administration } \\
\text { with MPTP }\end{array}$ & Striatum & Not evaluated & $\begin{array}{l}\text { (NC) TH (IHC) (NC) } \\
\text { lba-1 (IHC) }\end{array}$ & $\begin{array}{l}\text { (NC) time to descended in pole } \\
\text { test } \downarrow \text { latency to fell in rotarod }\end{array}$ & \multirow[t]{3}{*}{ Celorrio et al. (2017) } \\
\hline & & & & & SNpc & & (NC) TH $(\mathrm{IHC})$ & (CBD in animals control) & \\
\hline & $\begin{array}{l}\text { Haloperidol (dosage } \\
1 \mathrm{mg} / \mathrm{kg} \text { i.p.) }\end{array}$ & $\begin{array}{l}180 \mathrm{~min} \\
\text { induced } \\
\text { catalepsy }\end{array}$ & $\begin{array}{l}\mathrm{CBD}(5 \mathrm{mg} / \mathrm{kg} \text { and } \\
20 \mathrm{mg} / \mathrm{kg} \text { i.p.) }\end{array}$ & $\begin{array}{l}60 \mathrm{~min} \text {, administration } 2 \mathrm{~h} \text { after } \\
\text { injection of haloperidol }\end{array}$ & $\begin{array}{l}\text { Not } \\
\text { evaluated }\end{array}$ & Not evaluated & Not evaluated & $\begin{array}{l}\text { (NC) time in the bar test } \\
\text { catalepsy }\end{array}$ & \\
\hline \multirow[t]{4}{*}{ C57BL/6Mice } & $\begin{array}{l}\text { 6-OHDA [5 } \mu \mathrm{g} / 2 \mu \mathrm{l}] \\
\text { dorsolateral striatum } \\
\text { injection }\end{array}$ & $\begin{array}{l}21 \text { and } \\
38 \text { days }\end{array}$ & CBD (10 mg/kg i.p.) & $\begin{array}{l}\text { CBD chronic administration, } \\
14 \text { days; } 24 \text { days post 6- } \\
\text { OHDA }\end{array}$ & $\begin{array}{l}\text { Not } \\
\text { evaluated }\end{array}$ & Not evaluated & Not evaluated & $\uparrow$ latency in tail flick test & \multirow{4}{*}{$\begin{array}{l}\text { Crivelaro do } \\
\text { Nascimento et al. } \\
\text { (2020) }\end{array}$} \\
\hline & & & CBD (10 mg/kg i.p.) & $\begin{array}{l}\text { Acute administration, a single } \\
\text { injection at } 21 \text { days' post 6- } \\
\text { OHDA. }\end{array}$ & & & & $\begin{array}{l}\uparrow \text { latency in tail flick test } \uparrow \text { latency } \\
\text { hot plate test } \uparrow \text { latency to } \\
\text { mechanical stimulus in von frey } \\
\text { test } \uparrow \text { latency to cold stimulus in } \\
\text { acetone drop test }\end{array}$ & \\
\hline & & & CBD (30 mg/kg i.p.) & & & & & $\begin{array}{l}\downarrow \text { latency to mechanical stimulus } \\
\text { in von frey test } \downarrow \text { latency to cold } \\
\text { stimulus in acetone drop test }\end{array}$ & \\
\hline & & & CBD (100 mg/kg i.p.) & & & & & $\begin{array}{l}\uparrow \text { latency to mechanical stimulus } \\
\text { in von frey test } \uparrow \text { latency to cold } \\
\text { stimulus in acetone drop test }\end{array}$ & \\
\hline
\end{tabular}

6-OHDA, 6-hydroxydopamine; CBD, cannabidiol; DOPAC, dihydroxyphenylacetic; i.C.V, Intracerebroventricular; Iba-1, ionized calcium-binding adaptor protein-1; IHC, immunohistochemistry; ISH, in situ hybridization; MFB, medial forebrain bundle; MPTP, 1-methyl-4-phenyl-1,2,3,6-tetrahydropyridine; OX-42, oxycocin-42; PENK, proenkephalin; SNpc, substantia nigra pars compacta; SOD Cu/Zn, Copper Zinc - superoxide dismutase; SP, substance p; TH, tyrosine hydroxylase; ( $($ ) increase; ( $\downarrow)$ decrease; NC, no changes. 
The animal PD models most frequently used in preclinical research are administered neurotoxic agents such as 6-OHDA (mostly used in rats and mice) and MPTP (mostly used in monkeys and mice) (Duty and Jenner, 2011; Blesa et al., 2012). One of the goals of using an animal PD model is to study the drugs that prevent dopaminergic neuronal death. Attempts have been made to delay, or even arrest, dopaminergic degeneration with different chemicals, such as synthetic antioxidants (Moosmann and Behl, 2002), N-MethylD-aspartate receptor antagonists (NMDA) (Alexi et al., 2000; Olivares et al., 2012), $\mathrm{Ca}^{2+}$ channel blockers (Rodnitzky, 1999; Kang et al., 2012), and anti-inflammatory substances (McGeer et al., 2001; Martinez and Peplow, 2018). However, these pharmacological strategies, which aim to treat the main predisposing factors for $\mathrm{PD}$, are yet to yield satisfactory neuroprotection results.

The proposal of phytocannabinoids as a potential promoter of dopaminergic neuroprotection in animal PD models began with the work of Lastres-Becker et al. (2005) (Table 2), who administered THC and CBD every $24 \mathrm{~h}$ for 2 weeks at a dose of $3 \mathrm{mg} / \mathrm{kg}$ i.p., one day after injury with 6-OHDA in the medial bundle of the forebrain. They showed that THC and CBD play a neuroprotective role by decreasing dopaminergic neuronal death, although it should be note that CBD increased dopamine concentrations in the striatum. While a modification of the expression of the $\mathrm{CB} 1$ and $\mathrm{CB} 2$ receptors was not found in the 6-OHDA model, decreased TRPV1 receptor expression, a receptor expressed in the nigro-striatal pathway, was observed (Mezey et al., 2000).

Evidence of the neuroprotective effect of CBD may be found in a hemiparkinsonian model 6-OHDA injury. However, neurorestorative effects were not evident when CBD was administered one week after injury with 6-OHDA (GarcíaArencibia et al., 2007). The joint administration of intraperitoneal CBD and intrastriatal 6-OHDA showed increased levels in the mRNA of the enzyme superoxide dismutase $\mathrm{Cu} / \mathrm{Zn}$ (SOD Cu/Zn) (García-Arencibia et al., 2007), which suggests that CBD affects the expression of antioxidant enzymes, an effect which may, thus, decrease ROS levels in the striatum (Indo et al., 2015). In addition to the probable antioxidant role of $\mathrm{CBD}$, an antiinflammatory role was demonstrated when a marijuana extract enriched with CBD was administered to rats injured with 6-OHDA i.c.v. The dose was adjusted to an approximate concentration of $3 \mathrm{mg} / \mathrm{kg}$ and administered intraperitoneally. It was found that the decrease observed in the levels of OX-42, a marker of reactive microglia, may have induced an increase in the dopaminergic phenotype, as observed via $\mathrm{TH}$ immunohistochemistry conducted (García et al., 2011).

Other models of PD enable the evaluation of the effect of neuroprotective drugs. The neurotoxin reserpine decreases dopamine concentrations, leaving dopaminergic synaptic vesicles without a neurotransmitter, thus producing reversible parkinsonism. In an animal PD model, two $1 \mathrm{mg} / \mathrm{kg}$ reserpine doses were administered for six days along whit a CBD 0.5 and $5 \mathrm{mg}$ for seven days, resulting in a decrease in catalepsy behavior, a decrease in vacuous chewing movements, and an attenuation of reserpine-induced memory deficit (Peres et al., 2016). Another study found neither neuroprotective effect of CBD in 1-Methyl-4phenyl-1,2,3,6-tetrahydropyridine (MPTP) models in mice, nor beneficial effects on motor behavior or haloperidol-induced catalepsy (Celorrio et al., 2017).

Crivelaro do Nascimento et al. (2020) observed the neuroprotective effect of $\mathrm{CBD}$ in parkinsonian models in order to evaluate non-motor behaviors. After administrating 6-OHDA in the dorsolateral striatum for 21 days, they induced nosciceptive behaviors via the tail flick, hot plate, von frey, and acetone drop test, cannabidiol caused antinosciceptive effects at intraperioteneally administered doses of 10 and $1,000 \mathrm{mg} / \mathrm{kg}$ (Crivelaro do Nascimento et al., 2020). This antinosciceptive effect is likely to be more pronounced on interaction between CBD and the TRPV-1, CB2, and GPR55 receptors due to their analgesic and anti-inflammatory properties (Bisogno et al., 2001; Fernández-Ruiz et al., 2010b).

In vitro $\mathrm{PD}$ models enable the determination of the effect of neuroprotective drugs on cell viability, the modulatory role of the drug, and the signaling pathway that they active, namely the molecule of interest in the present study (Table 3). The most commonly studied cell culture has been the SH-SY5Y neuroblastoma culture, with one study finding that when the neurotoxic $\mathrm{MPP}^{+}$was administered at concentrations of 1 and $7 \mathrm{mM}$, phenotype and cell viability decreased. However, when CBD was administered at $10 \mu \mathrm{M}$, cell viability increased (Gugliandolo et al., 2020), although no differences were observed on the administration of either a 1 and $2.5 \mu \mathrm{M}$ CBD concentration (Carroll et al., 2012) and in 6-OHDA models (Schönhofen et al., 2015). In the $\mathrm{MPP}^{+}$model at concentrations of $100 \mu \mathrm{M}$, the protective effect of $1 \mu \mathrm{M}$ CBD concentrations was notable in PC12 pheocromocytoma cells, while increased cell differentiation and an increase in the NGF markers, synaptophysin, synapsin-1, and the GAP-43 protein, proteins that promote neural proliferation, were also observed (Santos et al., 2015). The mTOR pathway and the MAPK pathway, signaling pathways that promote cell survival and decrease the level of cell death markers such as Caspase- 3 and $\mathrm{Bax}$, are the signaling pathways that are activated by $\mathrm{CBD}$ (Gugliandolo et al., 2020).

\section{THE ROLE OF CANNABIDIOL IN LEVODOPA-INDUCED DYSKINESIA}

The word dyskinesia is derived from the Greek word dis, meaning difficult or abnormal, and kinesis, meaning movement, and is used to indicate abnormal involuntary movements (AIMs) (Rascol et al., 2010). Initially, the administration of L-3,4dihydroxyphenylalanine (L-DOPA), the precursor of DA, produces significant motor symptom improvements in $\mathrm{PD}$ patients, reducing tremor, muscle stiffness, difficulty initiating gait, and bradykinesia (slow movements) (Malek et al., 2019). The beneficial effects of L-DOPA last for approximately five years from the start of treatment, considered a "honeymoon period" between L-DOPA and PD, although they can sometimes last longer. After chronic L-DOPA administration, most patients develop motor fluctuations (on-off) or dyskinesias, due to increases and decreases in L-DOPA plasma levels (Cotzias et al., 1969). 
TABLE 3 | Research reports of effect CBD on various in vitro models of PD.

\begin{tabular}{|c|c|c|c|c|c|c|}
\hline $\begin{array}{l}\text { Cell } \\
\text { culture }\end{array}$ & $\begin{array}{l}\text { Cell toxicity } \\
\text { induced }\end{array}$ & $\begin{array}{l}\text { Temporary cell } \\
\text { toxicity }\end{array}$ & CBD treatment & $\begin{array}{l}\text { Biochemical } \\
\text { markers }\end{array}$ & Proteins evaluated & $\begin{array}{c}\text { Author } \\
\text { (Reference) }\end{array}$ \\
\hline $\begin{array}{l}\text { SH- } \\
\text { SY5Y }\end{array}$ & $\mathrm{MPP}^{+}[7 \mathrm{mM}]$ & $48 \mathrm{~h}$ & $\begin{array}{l}\text { CBD }[0.01,0.1 \text { y } 1 \mu \mathrm{M}] \text { Joint } \\
\text { administration with } \mathrm{MPP}^{+}\end{array}$ & (NC) LDH release & \multirow[t]{2}{*}{ Not evaluated } & $\begin{array}{l}\text { Carroll et al. } \\
(2012)\end{array}$ \\
\hline PC12 & $\begin{array}{l}\mathrm{MPP}^{+}[100 \mu \mathrm{M} \\
\text { and } 1 \mathrm{mM}]\end{array}$ & $24 \mathrm{~h}$ & $\begin{array}{l}\text { CBD }[1,5 \text { y } 10 \mu \mathrm{M}] \text { Joint } \\
\text { administration with } \mathrm{MPP}^{+}\end{array}$ & $\begin{array}{l}\uparrow \text { Cell viability MTT } \\
\text { assay }\end{array}$ & & $\begin{array}{l}\text { Santos et al. } \\
(2015)\end{array}$ \\
\hline & & $\begin{array}{c}72 \mathrm{~h} \\
72,96,120 \\
144,168 \mathrm{~h}\end{array}$ & $\mathrm{CBD}[1 \mu \mathrm{M}]$ & $\begin{array}{l}\uparrow \text { Differentiation } \\
\text { cellular } \\
\uparrow \text { Differentiation } \\
\text { cellular whitout } \mathrm{MPP}^{+}\end{array}$ & $\begin{array}{l}\uparrow \text { NGF (ELISA) } \uparrow \text { Synaptophysin (WB) } \uparrow \text { Synapsin I } \\
(\mathrm{WB}) \uparrow \text { GAP-43 (WB) }\end{array}$ & \\
\hline $\begin{array}{l}\text { SH- } \\
\text { SY5Y }\end{array}$ & Without toxin & Without toxin & CBD $[1 \mu \mathrm{M}] 72 \mathrm{~h}$ & $\begin{array}{l}\text { (NC) Differentiation } \\
\text { cellular }\end{array}$ & Not evaluated & \\
\hline $\begin{array}{l}\text { SH- } \\
\text { SY5Y }\end{array}$ & $\begin{array}{l}\text { 6-OHDA } \\
{[6.25 \mu \mathrm{M}]}\end{array}$ & $24 \mathrm{~h}$ & CBD $[2.5 \mu \mathrm{M}]$ & $\begin{array}{l}\text { (NC) Cell viability MTT } \\
\text { assay }\end{array}$ & \multirow[t]{2}{*}{ Not evaluated } & $\begin{array}{l}\text { Schönhofen } \\
\text { et al. (2015) }\end{array}$ \\
\hline $\begin{array}{l}\text { SH- } \\
\text { SY5Y }\end{array}$ & $\mathrm{MPP}^{+}[1 \mathrm{mM}]$ & $24 \mathrm{~h}$ & CBD $[10 \mu \mathrm{M}]$ & $\begin{array}{l}\uparrow \text { Cell viability MTT } \\
\text { assay }\end{array}$ & & $\begin{array}{l}\text { Gugliandolo } \\
\text { et al. (2020) }\end{array}$ \\
\hline & & $48 \mathrm{~h}$ & & & $\begin{array}{l}\downarrow \text { Caspase-3 (WB) } \downarrow \text { Bax (WB) } \downarrow \text { PARP-1 (WB } \uparrow \uparrow \mathrm{TH} \\
(\mathrm{WB}) \uparrow \mathrm{pERK} 1 / 2 / \mathrm{ERK} 2(\mathrm{WB}) \uparrow \mathrm{pAKT} / \mathrm{AKT}(\mathrm{WB}) \uparrow \\
\text { pmTOR/mTOR (WB) (NC) Beclin-1 (WB) } \downarrow \text { LC3-II/ } \\
\text { LC3-I (WB) }\end{array}$ & \\
\hline
\end{tabular}

6-OHDA, 6-hydroxydopamine; Bax, BCL2 associated X; CBD, cannabidiol; ELISA, enzyme-linked immunosorbent assay; GAP-43, growth associated protein 43; LC3, microtubuleassociated protein 1AV1B-light chain 3; LDH, lactate dehydrogenase; MPP', 1-methyl-4-phenylpyridinium; MTT, 3-(4,5-Dimethylthiazol-2-yl)-2,5-Diphenyltetrazolium Bromide; NGF, nerve growth factor; $p A K T$, protein kinase B phosphorylated; PARP-1, poly (ADP-ribose) polymerase-1; pERK, extracellular-signal-regulated kinase phosphorylated; pmTOR, mammalian target of rapamycin phosphorylated; $T H$, tyrosine hydroxylase; $W B$, western blot; $(\uparrow)$ increase; $(\downarrow)$ decrease; NC no changes.

Normally starting on the side contralateral to the hemisphere most affected by PD and occurring first in the lower extremities, LIDs are either choreiform or dystonic (Mones et al., 1971; Thanvi et al., 2007; Calabresi and Standaert, 2019). Factors such as the age of PD onset and its severity, gender, and the L-DOPA dose administered are factors related to the onset and intensity of LIDs (Eusebi et al., 2018; Zhou et al., 2019), which commonly affects the extremities, head, neck, and trunk, and are characterized by rapid and irregular movements (Luquin et al., 1992; Thanvi et al., 2007; Rascol et al., 2010).

L-DOPA-induced dyskinesias are classified in terms of the plasma levels of the drug administered and the appearance of certain symptoms post-administration. The symptoms that appear when L-DOPA concentrations are at their highest circulation, known as peak-dose dyskinesias, are characterized by stereotyped, ballistic, or choreiform movements (Luquin et al., 1992; Rascol et al., 2010) are usually the most common, and have the greatest impact on quality of life (Luquin et al., 1992; Pahwa et al., 2019). The dyskinesias that begin to occur when L-DOPA reaches its half-life have been termed diphasic and mainly cause rapidly alternating stereotyped movements in the legs (Luquin et al., 1992), as well as ballistic kicking or dystonia (Rascol et al., 2010; Pandey and Srivanitchapoom, 2017). Given that it occurs between the on and off phases, this period presents mixed dyskinesias, which occur at a low incidence and are difficult to treat (Luquin et al., 1992; Thanvi et al., 2007; Vijayakumar and Jankovic, 2016). When L-DOPA falls to a low level of circulation, the movements caused are known as off dyskinesias, in which patients usually suffer from a dystonic posture, especially in the morning (Marconi et al., 1994), and problematic lower limb sensations (Thanvi et al., 2007; Rascol et al., 2010).
Few studies have obtained evidence of the antidyskinetic activity of CBD, whit its pleiotropic effects (Devinsky et al., 2014) depending on the concentration administered (Jones et al., 2010). As determining the molecular mechanism that is involved in LIDs (see below) is a complex process, the preclinical and clinical evidence depends on the experimental design used to evaluate $\mathrm{CBD}$ as a potential treatment for reducing both PD symptoms and the adverse effects of L-DOPA administration. A study was conducted on tardive dyskinesias, which are related to the nigrostriatal pathway, which, itself, is affected by the administration of reserpine $(1 \mathrm{mg} / \mathrm{kg})$, a drug which has been shown to reduce glutamate consumption (Burger et al., 2005). Said research obtained favorable results in behavioral evaluations via the administration of CBD ( 0.5 and $5 \mathrm{mg} / \mathrm{kg}$ ), finding improved memory and reductions in oral dyskinesia and the cataleptic effect (Peres et al., 2016), which describes the subject's inability to correct an imposed posture (Pertwee, 1972), without modifying locomotor activity and anxiety in the model (Peres et al., 2016).

As previously mentioned, given that L-DOPA must be metabolized in the serotonergic neurons, the participation of these neurons in LIDs is an important factor to consider. It has been shown that the pharmacological silencing of serotonergic neurons can be accomplished via the agonists of serotonergic auto-receptors. Therefore, several studies show a decrease in LIDs as induced by selective agonists of the 5-HT1 receptors in animal models of PD (Bibbiani et al., 2001; Muñoz et al., 2008). As CBD has been shown to interact with the 5-HT1A receptor, this phytocannabinoid is able to modulate serotonergic neurotransmission (Magen et al., 2010; Zanelati et al., 2010; Espejo-Porras et al., 2013). In vitro studies have demonstrated that, at concentrations higher than $10 \mathrm{mM}, \mathrm{CBD}$ is able to activate $5-\mathrm{HT} 1 \mathrm{~A}$; however, at concentrations of $100 \mathrm{nM}$, it is 
also able to improve the agonist capacity of the 5-HT1A receptor in rat brainstem membranes (Rock et al., 2012). Given this effect of CBD on serotonergic receptors, it has been proposed as an anxiolytic (Gomes et al., 2011) and antidepressant agent (Zanelati et al., 2010). Moreover, it has been shown, at high doses ( $>10 \mathrm{mg} / \mathrm{kg}$ ), to modify motor behavior, wherein $20 \mathrm{mg} / \mathrm{kg}$ doses administered during motor behavior were not antagonized by rimonabant, a CB1 antagonist, but were antagonized by a selective 5-HT1A receptor antagonist (WAY100,635; $0.5 \mathrm{mg} / \mathrm{kg}$ ) (Espejo-Porras et al., 2013). These data demonstrate that $\mathrm{CBD}$ has significant effects on both motor behavior and the 5-HT1A receptor. While it is likely that CBD exerts effects on serotonergic receptors during LIDs, the ability of CBD to activate various mechanisms that exert a synergistic effect on PD and LIDs should not be excluded.

The antidyskinetic effect of CB1 activation, by means of AEA or WIN55212-2, is exhibited only when co-administered with a TRPV1 receptor antagonist (Morgese et al., 2007; Martinez et al., 2012; Martinez et al., 2015; Dos Santos-Pereira et al., 2016), namely capsazepine (CPZ) or N-arachidonoyl serotonin (AA-5-HT) (Dos Santos-Pereira et al., 2016). In addition, AA-5-HT inhibits the FAAH (Gobira et al., 2017) mechanism that increases concentrations of AEA, an ECB with a greater affinity with the CB1 receptor (Lam et al., 2005). However, the use of the TRPV1 antagonist $(\mathrm{CPZ})$ is necessary in order to demonstrate the antidyskinetic effects of the inhibition of FAAH. Promising results were obtained in research conducted on the 6-OHDA model in mice with a dorsolateral striatum lesion. After L-DOPA treatment for 21 days $(50 \mathrm{mg} / \mathrm{kg} /$ day, ip), CBD and capsazepine (CPZ, 1 and $5 \mathrm{mg} / \mathrm{kg}$, ip, respectively), an antagonist of TRPV1, were administered during the last days of an AIMs evaluation, showing a decrease in AIMs with the administration of CBD + CPZ (Dos Santos-Pereira et al., 2016). These results were similar to those obtained with the use of $\mathrm{N}$-araquidonoil serotonin (AA-5-HT), an eCB antagonist of FAAH and TRPV1 (Gobira et al., 2017). While these effects were previously evaluated using synthetic cannabinoids, with similar results obtained, it should be noted that the administration of WIN55212-2 (0.5 and $1 \mathrm{mg} / \mathrm{kg}$ ip) was shown to have antidyskinetic effects. Although the study's authors used WIN55212-2 as a selective agonist for CB1 (Martinez et al. 2012), it is known to have both a higher affinity for CB2 and the ability to inhibit TRPV1 (Morgese et al., 2007).

The mechanism by which AIMs are reduced by CBD + CPZ suggests that improving endocannabinoid tone and blocking TRPV1 receptors exerts a compensatory effect on aberrant endocannabinoid transmission, which occurs in the striatum of dyskinetic rats in 6-OHDA models after L-DOPA treatment (Wang et al., 2018). The increase in AEA, which preferentially activates CB1 over TRPV1 (McPartland et al., 2007; Lam et al., 2005), is the result of the inhibition of FAAH by CBD, which can also activate TRPV1 (Peres et al., 2018) (Figure 6). While stimulating CB1 alone reduces the hyperactivity of the cAMP/ PKA pathway, which has been implicated in the development of dyskinesias (Aubert et al., 2005; Martinez et al., 2012), the coactivation of CB1 and TRPV1 generates the opposite effect (Lam et al., 2005), with their participation in the induction of LTP also observed (Cui et al., 2018). This explains why CBD or FAAH antagonist (URB597) treatments do not reduce AIMs; however, when they are co-administered with $\mathrm{CPZ}$, they exert an antidyskinetic effect on all types of AIMs (Morgese et al., 2007; Martinez et al., 2015; Dos-Santos-Pereira et al., 2016).

An examination of the above-described mechanisms reveals evidence concurring with the results obtained via the subchronic administration of CBD + CPZ, which reduces the severity of LIDs and reduces the levels of biochemical markers such as pERK, pAcH3, NF- $\kappa \beta$, and COX-2 (Dos-Santos-Pereira et al., 2016), which increase with chronic L-DOPA treatment (Santini et al., 2007; Bastide et al., 2014). Both pERK and pAcH3 are generated by D1-receptor sensitization (Park et al., 2014), which maintains

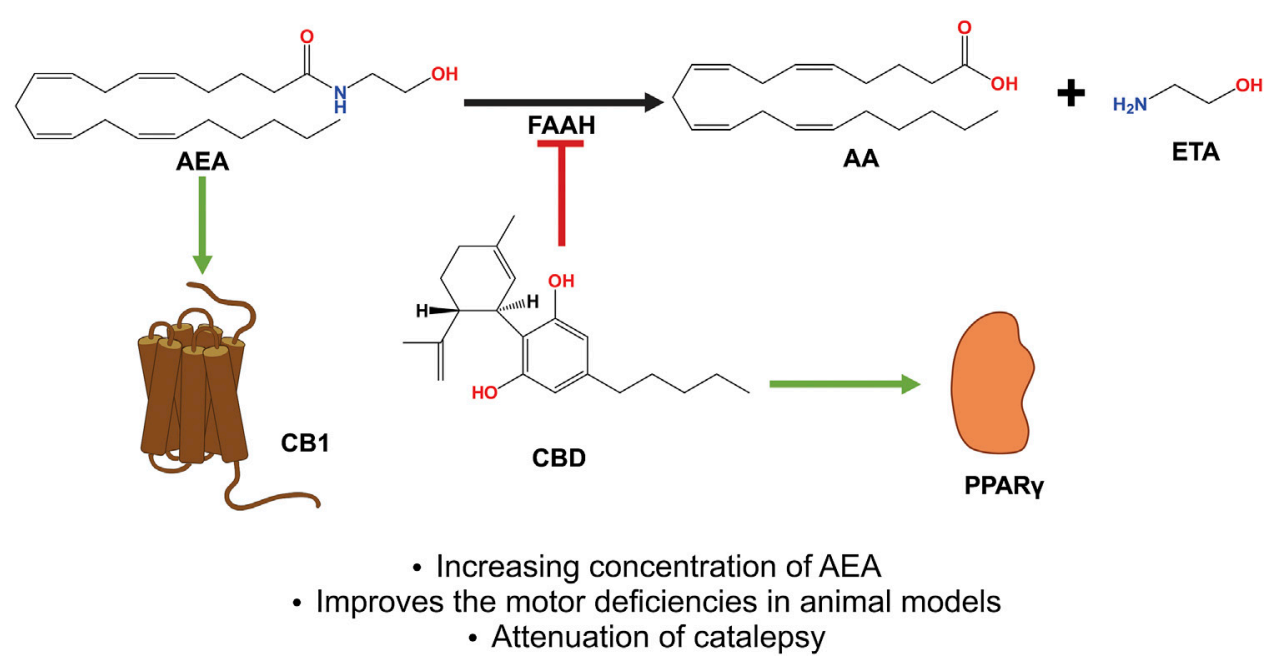

FIGURE 6 | CBD acts as an indirect agonist of the CB1 receptor by inhibiting the enzyme that degrades $A E A$ and FAAH, thus increasing the concentration of said eCB, which has a greater affinity to activating $\mathrm{CB} 1$, thus exerting neuroprotective and antiparkinsonian effects. In addition, CBD activates the PPAR $\gamma$ receptors, which have been shown to be involved in neuroinflammatory processes. Abbreviations: CBD, cannabidiol; CB1, cannabinoid receptor type 1; AEA, anandamide; FAAH, fatty acid amide hydrolase; eCB, endocannabinoids; PPAR $\gamma$, peroxisome proliferator activated receptor $\gamma$. 


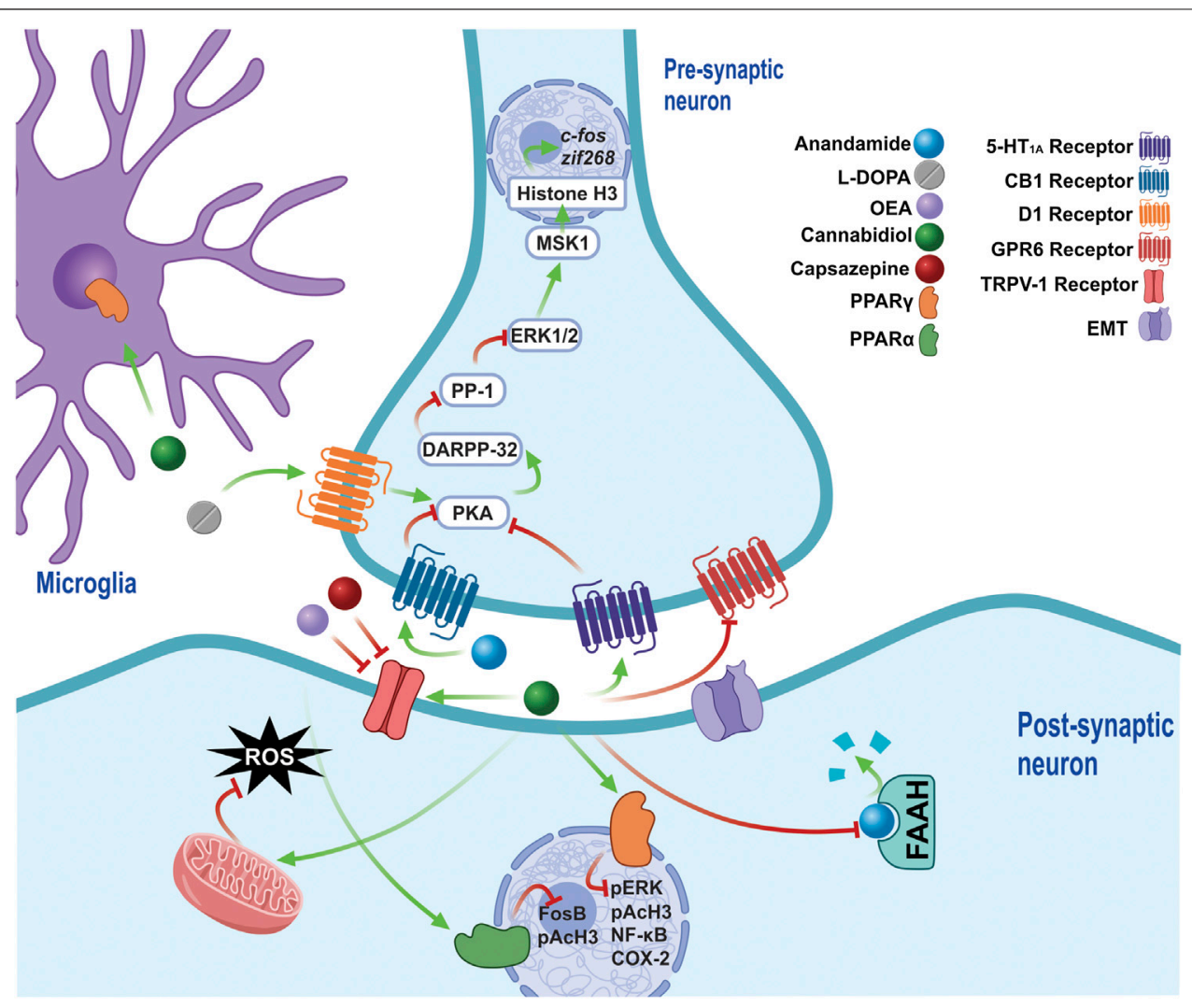

FIGURE 7 | The chronic administration of L-DOPA leads to a sensitization of D1 receptors, which maintain the over-activation of PKA in LIDs. PKA regulates the pathway that activates DARPP-32, which inhibits the modification by PP-1, of ERK1/2 signaling, which acts on nuclear targets, such as MSK1, and, along with histone $\mathrm{H} 3$, regulates the expression of early genes such as c-fos and zif268. CBD exerts antidyskinetic effects by increasing AEA concentration by inhibiting of FAAH, thus stimulating the CB1 receptors, which decrease PKA activity. The CB1 requiere the co-administration of a TRPV1 inhibitor (CPZ), because they stimulate TRPV1 via $\mathrm{AEA}$ and $\mathrm{CBD}$, both of which generate opposite effects to the activation of $\mathrm{CB} 1$. Furthermore, increased OEA is generated via the inhibition of $\mathrm{FAAH}$, an endocannabinoid able to block TRPV1 and stimulate PPAR $\sigma$ receptors, reducing biochemical markers such as FosB and pAcH3. In addition, CBD activate the 5-HT1A receptor, a receptor that had previously only been implicated in the anticataleptic effect of CBD. By activating PPAR $\gamma$ receptors, CBD reduces the levels of molecular markers involved in LIDs, such as pERK, pAcH3, NF-K $\beta$ and COX-2, while it also generates an anti-inflammatory effect by stimulating said receptors, which are present in the glia. Furthermore, $\mathrm{CBD}$ is able to reduce oxidative damage, decreasing the production of ROS by increasing the activity of mitochondrial complexes. The inverse agonism that CBD exerts on GPR6 could form part of its antidyskinetic mechanisms. Abbreviations: L-DOPA, L-3,4-Dihydroxyphenylalanine; D1, Dopamine receptor 1; PKA, cAMPdependent protein kinase; LID, L-DOPA-induced dyskinesias; DARPP-32-32 KDa Phosphoprotein regulated by cAMP and dopamine; PP-1, phosphoprotein 1; ERK, extracellular signal-regulated kinase; MSK-1, mitogen and stress regulated protein kinase; CBD, cannabidiol; AEA, anandamide; FAAH, fatty acid amide hydrolase; TRPV1, transient potential receptor V1; CPZ, cpazazepine; OEA, oleoylethanolamide; PPARa, peroxisome proliferator activated receptor a; pAcH3, Histone 3 phosphoacetylation; 5HT1A, Serotonin receptor 1A; PPAR $\gamma$, peroxisome proliferator activated receptor $\gamma$; NF-K $\beta$, nuclear factor K $\beta$; COX-2, cyclooxygenase 2 .

an overactivated signaling pathway and which, in turn, results in an increase in the level of these markers (Aubert et al., 2005). NF$\kappa \beta$ and COX- 2 are characteristic of a neuroinflammatory process, with their levels increasing due to the depletion of DA and the neurotoxicity caused by L-DOPA (Bortolanza et al., 2015; Pisanu et al., 2018), while a reduction in their levels causes the activation of PPAR $\gamma$ (Randy and Guoying, 2007) and occurs due to CBD's own anti-inflammatory effects (Peres et al., 2018).

It has been shown that the administration of the eCB oleoylethanolamide (OEA) generates antidyskinetic effects (González-Aparicio and Moratalla, 2014), results which show that its mechanisms block TRPV1 and stimulate PPARo (Almási et al., 2008; Thabuis et al., 2008). Moreover, a decrease in the levels of markers such as FosB and $\mathrm{pAcH} 3$ has also been observed (González-Aparicio and Moratalla, 2014). In addition, an increase in the concentration of OEA has been reported with the administration of URB597 in an EP model injured with MPTP (Celorrio et al., 2016), as it shares the same degradation pathway as AEA (Figure 7) (Thabuis et al., 2008), with the same study also observing a motor deficit improvement (Celorrio et al., 2016).

Other molecular targets of CBD, such as the GPR6 orphan receptor, which is mainly expressed in the striato-pallidal neurons of the striatum, have been studied in recent years (Lobo et al., 2007). One study found an AIMs reduction in knockout mice after GPR6 ablation, as well as a cAMP reduction and an increase in both DA levels and the phosphorylation of DARPP-32 in the striatum. This suggests that blocking GPR6 exerts an antidyskinetic effect (Oeckl et al., 2014), with research showing that CBD acts as an inverse agonist on GPR6 (Laun and Song, 2017), an effect forming part of its therapeutic mechanisms. 
Clinical evaluations of CBD have found improvements in terms of certain symptoms, depending on the doses administered (Jones et al., 2010). In an open preliminary pilot study, which evaluated dystonia under weekly CBD dose escalations (100 mg/week), one of the patients, who was received $1,000 \mathrm{mg}$ /day L-DOPA doses, presented a 50\% improvement (Consroe et al., 1986). Given that it is a type of LID (Marconi et al., 1994), the use of CBD, at appropriate doses, is suggested to reduce the severity of dystonia. An increase in hypokinesia has been reported with the administration of high CBD doses (300-400 mg/day); however, there is currently no complete understanding of its pharmacokinetics, although significant improvements in symptoms have been observed in a dosage range of $1-50 \mathrm{mg} / \mathrm{kg} /$ day in different pathologies (Millar et al., 2019). Furthermore, no changes were found when quantifying brain-derived neurotrophic factor (BDNF), the level of which decreases in $\mathrm{PD}$, while a greater susceptibility to LID was found in patients with a polymorphism in the gene encoding BNDF (Howells et al., 2000; Foltynie et al., 2009). Both the increase in BDNF (Sales et al., 2019) and the improvement in LID symptoms that can be caused by CBD require further study in order to be applied in clinical practice. Moreover, it must also be established whether results improve with the use of other phytocannabinoids that exert a synergistic effect (Samarut et al., 2019).

\section{CONCLUSION}

The bibliographic evidence shown in the present review suggests the clinical utility of CBD for treating both LIDs and the motor symptoms of $\mathrm{PD}$, as well as the neuromodulatory, neuroprotective and antidyskinetic effects of $\mathrm{CBD}$ in animal models and $\mathrm{pD}$. Furthermore, the evidence shown on the pharmacological

\section{REFERENCES}

Albin, R. L., Young, A. B., and Penney, J. B. (1989). The functional anatomy of basal ganglia disorders. Trends Neurosci. 12, 366-375. doi:10.1016/0166-2236(89) 90074-x

Alexander, G. E., and Crutcher, M. D. (1990). Functional architecture of basal ganglia circuits: neural substrates of parallel processing. Trends Neurosci. 13 (7), 266-271. doi:10.1016/0166-2236(90)90107-1

Alexi, T., Borlongan, C. V., Faull, R. L., Williams, C. E., Clark, R. G., Gluckman, P. D., et al. (2000). Neuroprotective strategies for basal ganglia degeneration: Parkinson's and Huntington's diseases. Prog. Neurobiol. 60 (5), 409-470. doi:10.1016/s0301-0082(99)00032-5

Alhouayek, M., Masquelier, J., and Muccioli, G. G. (2018). Lysophosphatidylinositols, from cell membrane constituents to GPR55 ligands. Trends Pharmacol. Sci. 39 (6), 586-604. doi:10.1016/j.tips.2018.02.011

Almási, R., Szoke, E., Bölcskei, K., Varga, A., Riedl, Z., Sándor, Z., et al. (2008). Actions of 3-methyl-N-oleoyldopamine, 4-methyl-N-oleoyldopamine and $\mathrm{N}$-oleoylethanolamide on the rat TRPV1 receptor in vitro and in vivo. Life Sci. 82 (11-12), 644-651. doi:10.1016/j.lfs.2007.12.022

Arai, R., Karasawa, N., Geffard, M., and Nagatsu, I. (1995). L-DOPA is converted to dopamine in serotonergic fibers of the striatum of the rat: a double-labeling immunofluorescence study. Neurosci. Lett. 195 (3), 195-198. doi:10.1016/03043940(95)11817-g

Arellano, A. L., Papaseit, E., Romaguera, A., Torrens, M., and Farré, M. (2017). Neuropsychiatric and general interactions of natural and synthetic cannabinoids with drugs of abuse and medicines. CNS Neurol. Disord.-Drug Targets 16 (5), 554-566. doi:10.2174/1871527316666170413104516 mechanisms and molecular interactions of $\mathrm{CBD}$ with various receptors may explain the wide range of therapeutic utility in various neurological disorders.

Despite the promising results for CBD pharmacology, unknowns remain about dosages and mechanisms of action. However, the essential role of $\mathrm{CBD}$ as an antioxidant and anti-inflammatory is affirmed, as these processes are important in the pathogenesis of $p \mathrm{D}$. The neuromodulatory mechanism of CBD in the BG circuit remains to be studied in greater depth, in order to establish this phytocannabinoid's physiological role and function as a coadjuvant in PD.

\section{AUTHOR CONTRIBUTIONS}

FP, AM-A, AP-M, and IL performed the bibliography searches and participated in the manuscript writing, all authors reviewed and approved the final version of the manuscript. FP and AM-A made all the figures in this review.

\section{FUNDING}

This study was supported by grants from VIEP-BUAP 20192020, awarded to IL, while FP-received support via a scholarship from CONACYT-Mexico (732793).

\section{ACKNOWLEDGMENTS}

Thanks to Benjamin Stewart (native English speaker and academic proof-reader) for editing the English language text.

Ascherio, A., and Schwarzschild, M. A. (2016). The epidemiology of Parkinson's disease: risk factors and prevention. Lancet Neurol. 15 (12), 1257-1272. doi:10. 1016/S1474-4422(16)30230-7

Aubert, I., Guigoni, C., Håkansson, K., Li, Q., Dovero, S., Barthe, N., et al. (2005). Increased D1 dopamine receptor signaling in levodopa-induced dyskinesia. Ann. Neurol. 57 (1), 17-26. doi:10.1002/ana.20296

Bachiller, S., Jiménez-Ferrer, I., Paulus, A., Yang, Y., Swanberg, M., Deierborg, T. et al. (2018). Microglia in neurological diseases: a road map to brain-disease dependent-inflammatory response. Front. Cell. Neurosci. 12, 488. doi:10.3389/ fncel.2018.00488

Bastide, M. F., Dovero, S., Charron, G., Porras, G., Gross, C. E., Fernagut, P. O., et al. (2014). Immediate-early gene expression in structures outside the basal ganglia is associated to 1-DOPA-induced dyskinesia. Neurobiol. Dis. 62, 179-192. doi:10.1016/j.nbd.2013.09.020

Benito, C., Kim, W. K., Chavarría, I., Hillard, C. J., Mackie, K., Tolón, R. M., et al. (2005). A glial endogenous cannabinoid system is upregulated in the brains of macaques with simian immunodeficiency virus-induced encephalitis. J. Neurosci. 25 (10), 2530-2536. doi:10.1523/JNEUROSCI.3923-04.2005

Bibbiani, F., Oh, J. D., and Chase, T. N. (2001). Serotonin 5-HT1A agonist improves motor complications in rodent and primate parkinsonian models. Neurology 57 (10), 1829-1834. doi:10.1212/wnl.57.10.1829

Birkmayer, W., and Hornykiewicz, O. (1961). The L-3,4-dioxyphenylalanine (DOPA)-effect in parkinson-akinesia. Wien Klin. Wochenschr. 73, 787-788

Bisogno, T., Hanus, L., De Petrocellis, L., Tchilibon, S., Ponde, D. E., Brandi, I., et al. (2001). Molecular targets for cannabidiol and its synthetic analogues: effect on vanilloid VR1 receptors and on the cellular uptake and enzymatic hydrolysis of anandamide. Br. J. Pharmacol. 134 (4), 845-852. doi:10.1038/ sj.bjp.0704327 
Blesa, J., Phani, S., Jackson-Lewis, V., and Przedborski, S. (2012). Classic and new animal models of parkinson's disease. J. Biomed. Biotechnol. 2012, 845618. doi: $10.1155 / 2012 / 845618$

Blume, L. C., Bass, C. E., Childers, S. R., Dalton, G. D., Roberts, D. C., Richardson, J. M., et al. (2013). Striatal CB1 and D2 receptors regulate expression of each other, CRIP1A and $\delta$ opioid systems. J. Neurochem. 124 (6), 808-820. doi:10. 1111/jnc.12139

Bogetofte, H., Alamyar, A., Blaabjerg, M., and Meyer, M. (2020). Levodopa therapy for parkinson's disease: history, current status and perspectives. CNS Neurol. Disord. Drug Targets [Epub ahead of print]. doi:10.2174/ 1871527319666200722153156

Bornheim, L. M., and Grillo, M. P. (1998). Characterization of cytochrome P450 3A inactivation by cannabidiol: possible involvement of cannabidiolhydroxyquinone as a P450 inactivator. Chem. Res. Toxicol. 11 (10), 1209-1216. doi:10.1021/tx9800598

Bortolanza, M., Padovan-Neto, F. E., Cavalcanti-Kiwiatkoski, R., Dos SantosPereira, M., Mitkovski, M., Raisman-Vozari, R., et al. (2015). Are cyclooxygenase-2 and nitric oxide involved in the dyskinesia of parkinson's disease induced by L-DOPA?. Philos. Trans. R. Soc. Lond. B Biol. Sci. 370 (1672), 20140190. doi:10.1098/rstb.2014.0190

Bouaboula, M., Hilairet, S., Marchand, J., Fajas, L., Le Fur, G., and Casellas, P. (2005). Anandamide induced PPARgamma transcriptional activation and 3T3L1 preadipocyte differentiation. Eur. J. Pharmacol. 517 (3), 174-181. doi:10. 1016/j.ejphar.2005.05.032

Brown, K. J., Laun, A. S., and Song, Z. H. (2017). Cannabidiol, a novel inverse agonist for GPR12. Biochem. Biophys. Res. Commun. 493 (1), 451-454. doi:10. 1016/j.bbrc.2017.09.001

Burger, M. E., Fachineto, R., Alves, A., Callegari, L., and Rocha, J. B. (2005). Acute reserpine and subchronic haloperidol treatments change synaptosomal brain glutamate uptake and elicit orofacial dyskinesia in rats. Brain Res. 1031 (2), 202-210. doi:10.1016/j.brainres.2004.10.038

Calabresi, P., and Standaert, D. G. (2019). Dystonia and levodopa-induced dyskinesias in parkinson's disease: is there a connection?. Neurobiol. Dis. 132, 104579. doi:10.1016/j.nbd.2019.104579

Calapai, F., Cardia, L., Sorbara, E. E., Navarra, M., Gangemi, S., Calapai, G., et al. (2020). Cannabinoids, blood-brain barrier, and brain disposition. Pharmaceutics 12 (3), 265. doi:10.3390/pharmaceutics 12030265

Carlini, E. A., Mechoulam, R., and Lander, N. (1975). Anticonvulsant activity of four oxygenated cannabidiol derivatives. Res. Commun. Chem. Pathol. Pharmacol. 12 (1), 1-15

Carlsson, A., Lindqvist, M., and Magnusson, T. (1957). 3,4Dihydroxyphenylalanine and 5-hydroxytryptophan as reserpine antagonists. Nature 180 (4596), 1200. doi:10.1038/1801200a0

Carrier, E. J., Auchampach, J. A., and Hillard, C. J. (2006). Inhibition of an equilibrative nucleoside transporter by cannabidiol: a mechanism of cannabinoid immunosuppression. Proc. Natl. Acad. Sci. U.S.A. 103, 7895-7900. doi:10.1073/pnas.0511232103

Carrier, E. J., Kearn, C. S., Barkmeier, A. J., Breese, N. M., Yang, W., Nithipatikom, K., et al. (2004). Cultured rat microglial cells synthesize the endocannabinoid 2arachidonylglycerol, which increases proliferation via a CB2 receptordependent mechanism. Mol. Pharmacol. 65 (4), 999-1007. doi:10.1124/mol. 65.4 .999

Carroll, C. B., Bain, P. G., Teare, L., Liu, X., Joint, C., Wroath, C., et al. (2004). Cannabis for dyskinesia in Parkinson disease: a randomized double-blind crossover study. Neurology 63 (7), 1245-1250. doi:10.1212/01.wnl. $0000140288.48796 .8 \mathrm{e}$

Carroll, C. B., Zeissler, M. L., Hanemann, C. O., and Zajicek, J. P. (2012). $\Delta^{9}$-tetrahydrocannabinol $\left(\Delta^{9}\right.$-THC) exerts a direct neuroprotective effect in a human cell culture model of Parkinson's disease. Neuropathol. Appl. Neurobiol. 38 (6), 535-547. doi:10.1111/j.1365-2990.2011.01248.x

Carta, M., and Bezard, E. (2011). Contribution of pre-synaptic mechanisms to L-DOPA-induced dyskinesia. Neuroscience 198, 245-251. doi:10.1016/j. neuroscience.2011.07.070

Cascio, M. G., and Pertwee, R. G. (2014). "Known pharmacological actions of nine nonpsychotropic phytocannabinoids," in Handbook of cannabis. Editor R. G. Pertwee (New York: Oxford University Press), 137-156.

Cassano, T., Calcagnini, S., Pace, L., De Marco, F., Romano, A., and Gaetani, S. (2017). Cannabinoid receptor 2 signaling in neurodegenerative disorders: from pathogenesis to a promising therapeutic target. Front. Neurosci. 11, 30. doi:10. 3389/fnins.2017.00030

Celorrio, M., Fernández-Suárez, D., Rojo-Bustamante, E., Echeverry-Alzate, V., Ramírez, M. J., Hillard, C. J., et al. (2016). Fatty acid amide hydrolase inhibition for the symptomatic relief of Parkinson's disease. Brain Behav. Immun. 57, 94-105. doi:10.1016/j.bbi.2016.06.010

Celorrio, M., Rojo-Bustamante, E., Fernández-Suárez, D., Sáez, E., EstellaHermoso de Mendoza, A., et al. (2017). GPR55: a therapeutic target for parkinson's disease?. Neuropharmacology 125, 319-332. doi:10.1016/j. neuropharm.2017.08.017

Chagas, M. H. N., Eckeli, A. L., Zuardi, A. W., Pena-Pereira, M. A., Sobreira-Neto, M. A., Sobreira, E. T., et al. (2014a). Cannabidiol can improve complex sleeprelated behaviours associated with rapid eye movement sleep behaviour disorder in parkinson's disease patients: a case series. J. Clin. Pharm. Ther. 39, 564-566. doi:10.1111/jcpt.12179

Chagas, M. H. N., Zuardi, A. W., Tumas, V., Pena-Pereira, M. A., Sobreira, E. T., Bergamaschi, M. M., et al. (2014b). Effects of cannabidiol in the treatment of patients with Parkinson's disease: an exploratory doubleblind trial. J. Psychopharmacol. 28 (11), 1088-1098. doi:10.1177/ 0269881114550355

Chaves-Kirsten, G. P., Mazucanti, C. H., Real, C. C., Souza, B. M., Britto, L. R., and Torrão, A. S. (2013). Temporal changes of CB1 cannabinoid receptor in the basal ganglia as a possible structure-specific plasticity process in 6-OHDA lesioned rats. PLoS One 8 (10), e76874. doi:10.1371/journal.pone.0076874

Chen, Y., and Buck, J. (2000). Cannabinoids protect cells from oxidative cell death: a receptor-independent mechanism. J. Pharmacol. Exp. Ther. 293 (3), 807-812. https://jpet.aspetjournals.org/content/293/3/807.long

Cheng, H. C., Ulane, C. M., and Burke, R. E. (2010). Clinical progression in Parkinson disease and the neurobiology of axons. Ann. Neurol. 67 (6), 715-725. doi:10.1002/ana.21995

Choonara, Y. E., Pillay, V., du Toit, L. C., Modi, G., Naidoo, D., Ndesendo, V. M., et al. (2009). Trends in the molecular pathogenesis and clinical therapeutics of common neurodegenerative disorders. Int. J. Mol. Sci. 10 (6), 2510-2557. doi:10.3390/ijms 10062510

Chung, H., Fierro, A., and Pessoa-Mahana, C. D. (2019). Cannabidiol binding and negative allosteric modulation at the cannabinoid type 1 receptor in the presence of delta-9-tetrahydrocannabinol: an in silico study. PLoS One 14 (7), e0220025. doi:10.1371/journal.pone.0220025

Chung, Y. C., Bok, E., Huh, S. H., Park, J. Y., Yoon, S. H., Kim, S. R., et al. (2011). Cannabinoid receptor type 1 protects nigrostriatal dopaminergic neurons against MPTP neurotoxicity by inhibiting microglial activation. J. Immunol. 187 (12), 6508-6517. doi:10.4049/jimmunol.1102435

Clarke, C. E. (2007). Parkinson's disease. BMJ 335 (7617), 441-445. doi:10.1136/ bmj.39289.437454.AD

Colombo, E., and Farina, C. (2016). Astrocytes: key regulators of neuroinflammation. Trends Immunol. 37 (9), 608-620. doi:10.1016/j.it.2016.06.006

Console-Bram, L., Brailoiu, E., Brailoiu, G. C., Sharir, H., and Abood, M. E. (2014). Activation of GPR18 by cannabinoid compounds: a tale of biased agonism. Br. J. Pharmacol. 171 (16), 3908-3917. doi:10.1111/bph.12746

Consroe, P., Sandyk, R., and Snider, S. R. (1986). Open label evaluation of cannabidiol in dystonic movement disorders. Int. J. Neurosci. 30 (4), 277-282. doi:10.3109/00207458608985678

Costa, B., Colleoni, M., Conti, S., Parolaro, D., Franke, C., Trovato, A. E., et al. (2004). Oral anti-inflammatory activity of cannabidiol, a non-psychoactive constituent of cannabis, in acute carrageenan-induced inflammation in the rat paw. Naunyn Schmiedebergs Arch. Pharmacol. 369 (3), 294-299. doi:10.1007/ s00210-004-0871-3

Cotzias, G. C., Papavasiliou, P. S., and Gellene, R. (1969). Modification of parkinsonism-chronic treatment with L-dopa. N. Engl. J. Med. 280 (7), 337-345. doi:10.1056/NEJM196902132800701

Covey, D. P., Mateo, Y., Sulzer, D., Cheer, J. F., and Lovinger, D. M. (2017). Endocannabinoid modulation of dopamine neurotransmission. Neuropharmacology 124, 52-61. doi:10.1016/j.neuropharm.2017.04.033

Cristino, L., de Petrocellis, L., Pryce, G., Baker, D., Guglielmotti, V., and Di Marzo, V. (2006). Immunohistochemical localization of cannabinoid type 1 and vanilloid transient receptor potential vanilloid type 1 receptors in the mouse brain. Neuroscience 139 (4), 1405-1415. doi:10.1016/j.neuroscience. 2006.02.074 
Crivelaro do Nascimento, G., Ferrari, D. P., Guimaraes, F. S., Del Bel, E. A., Bortolanza, M., and Ferreira-Junior, N. C. (2020). Cannabidiol increases the nociceptive threshold in a preclinical model of parkinson's disease. Neuropharmacology 163, 107808. doi:10.1016/j.neuropharm.2019.107808

Cui, Y., Perez, S., and Venance, L. (2018). Endocannabinoid-LTP mediated by CB1 and TRPV1 receptors encodes for limited occurrences of coincident activity in neocortex. Front. Cell. Neurosci. 12, 182. doi:10.3389/fncel.2018. 00182

da Silva, J. A., Biagioni, A. F., Almada, R. C., de Souza Crippa, J. A., Cecílio Hallak, J. E., Zuardi, A. W., et al. (2015). Dissociation between the panicolytic effect of cannabidiol microinjected into the substantia nigra, pars reticulata, and fearinduced antinociception elicited by bicuculline administration in deep layers of the superior colliculus: the role of CB1-cannabinoid receptor in the ventral mesencephalon. Eur. J. Pharmacol. 758, 153-163. doi:10.1016/j.ejphar.2015. 03.051

Dalton, W. S., Martz, R., Lemberger, L., Rodda, B. E., and Forney, R. B. (1976). Influence of cannabidiol on delta-9-tetrahydrocannabinol effects. Clin. Pharmacol. Ther. 19 (3), 300-309. doi:10.1002/cpt1976193300

Dariš, B., Tancer Verboten, M., Knez, Ž., and Ferk, P. (2019). Cannabinoids in cancer treatment: therapeutic potential and legislation. Bosn. J. Basic Med. Sci. 19 (1), 14-23. doi:10.17305/bjbms.2018.3532

de Faria, S. M., de Morais Fabrício, D., Tumas, V., Castro, P. C., Ponti, M. A., Hallak, J. E., et al. (2020). Effects of acute cannabidiol administration on anxiety and tremors induced by a simulated public speaking test in patients with Parkinson's disease. J. Psychopharmacol., 34 (2), 189-196. doi:10.1177/ 0269881119895536

De Petrocellis, L., Ligresti, A., Moriello, A. S., Allarà, M., Bisogno, T., Petrosino, S., et al. (2011). Effects of cannabinoids and cannabinoid-enriched Cannabis extracts on TRP channels and endocannabinoid metabolic enzymes. $B r$. J. Pharmacol. 163 (7), 1479-1494. doi:10.1111/j.1476-5381.2010.01166.x

DeLong, M. R. (1990). Primate models of movement disorders of basal ganglia origin. Trends Neurosci. 13 (7), 281-285. doi:10.1016/0166-2236(90)90110-v

Deng, H., Wang, P., and Jankovic, J. (2018). The genetics of Parkinson disease. Ageing Res. Rev. 42, 72-85. doi:10.1016/j.arr.2017.12.007

Devane, W. A., Hanus, L., Breuer, A., Pertwee, R. G., Stevenson, L. A., Griffin, G., et al. (1992). Isolation and structure of a brain constituent that binds to the cannabinoid receptor. Science 258 (5090), 1946-1949. doi:10.1126/science. 1470919

Devinsky, O., Cilio, M. R., Cross, H., Fernandez-Ruiz, J., French, J., Hill, C., et al. (2014). Cannabidiol: pharmacology and potential therapeutic role in epilepsy and other neuropsychiatric disorders. Epilepsia 55 (6), 791-802. doi:10.1111/ epi.12631

Devinsky, O., Patel, A. D., Thiele, E. A., Wong, M. H., Appleton, R., Harden, C. L., et al. (2018). GWPCARE1 Part A Study GroupRandomized, dose-ranging safety trial of cannabidiol in Dravet syndrome. Neurology 90 (14), e1204-e1211. doi:10.1212/WNL.0000000000005254

Di Marzo, V., Melck, D., Bisogno, T., and De Petrocellis, L. (1998). Endocannabinoids: endogenous cannabinoid receptor ligands with neuromodulatory action. Trends Neurosci. 21 (12), 521-528. doi:10.1016/ s0166-2236(98)01283-1

Di Marzo, V., Stella, N., and Zimmer, A. (2015). Endocannabinoid signalling and the deteriorating brain. Nat. Rev. Neurosci. 16 (1), 30-42. doi:10.1038/ nrn3876

Diao, H. L., Xue, Y., Han, X. H., Wang, S. Y., Liu, C., Chen, W. F., et al. (2017). Adenosine A2A receptor modulates the activity of globus pallidus neurons in rats. Front. Physiol. 8, 897. doi:10.3389/fphys.2017.00897

Ding, Y. M., Jaumotte, J. D., Signore, A. P., and Zigmond, M. J. (2004). Effects of 6hydroxydopamine on primary cultures of substantia nigra: specific damage to dopamine neurons and the impact of glial cell line-derived neurotrophic factor. J. Neurochem. 89 (3), 776-787. doi:10.1111/j.1471-4159.2004.02415.x

Domingues, A. V., Pereira, I. M., Vilaça-Faria, H., Salgado, A. J., Rodrigues, A. J., and Teixeira, F. G. (2020). Glial cells in Parkinson's disease: protective or deleterious?. Cell. Mol. Life Sci. 77 (24), 5171-5188. doi:10.1007/s00018-02003584-x

Dos-Santos-Pereira, M., da-Silva, C. A., Guimarães, F. S., and Del-Bel, E. (2016). Co-administration of cannabidiol and capsazepine reduces L-DOPA-induced dyskinesia in mice: possible mechanism of action. Neurobiol. Dis. 94, 179-195. doi:10.1016/j.nbd.2016.06.013
Duty, S., and Jenner, P. (2011). Animal models of Parkinson's disease: a source of novel treatments and clues to the cause of the disease. Br. J. Pharmacol. 164 (4), 1357-1391. doi:10.1111/j.1476-5381.2011.01426.x

Echeverry, C., Prunell, G., Narbondo, C., de Medina, V. S., Nadal, X., Reyes-Parada, M., et al. (2020). A comparative in vitro study of the neuroprotective effect induced by cannabidiol, cannabigerol, and their respective acid forms: relevance of the 5-htla receptors. Neurotox. Res. [Epub ahead of print]. doi:10.1007/ s12640-020-00277-y

Espejo-Porras, F., Fernández-Ruiz, J., Pertwee, R. G., Mechoulam, R., and García, C. (2013). Motor effects of the non-psychotropic phytocannabinoid cannabidiol that are mediated by 5-HT1A receptors. Neuropharmacology 75, 155-163. doi:10.1016/j.neuropharm.2013.07.024

Esposito, G., De Filippis, D., Maiuri, M. C., De Stefano, D., Carnuccio, R., and Iuvone, T. (2006). Cannabidiol inhibits inducible nitric oxide synthase protein expression and nitric oxide production in beta-amyloid stimulated PC12 neurons through p38 MAP kinase and NF-kappaB involvement. Neurosci. Lett. 399 (1-2), 91-95. doi:10.1016/j.neulet.2006.01.047

Esposito, G., Scuderi, C., Valenza, M., Togna, G. I., Latina, V., De Filippis, D., et al. (2011). Cannabidiol reduces $A \beta$-induced neuroinflammation and promotes hippocampal neurogenesis through PPAR $\gamma$ involvement. PLoS One 6 (12), e28668. doi:10.1371/journal.pone.0028668

Eusebi, P., Romoli, M., Paoletti, F. P., Tambasco, N., Calabresi, P., and Parnetti, L. (2018). Risk factors of levodopa-induced dyskinesia in Parkinson's disease: results from the PPMI cohort. NPJ Parkinsons Dis. 4, 33. doi:10.1038/s41531018-0069-x

Fernández-Ruiz, J., Hernández, M., and Ramos, J. A. (2010a). Cannabinoiddopamine interaction in the pathophysiology and treatment of CNS disorders. CNS Neurosci. Ther. 16 (3), e72-e91. doi:10.1111/j.1755-5949. 2010.00144.x

Fernández-Ruiz, J., García, C., Sagredo, O., Gómez-Ruiz, M., and de Lago, E. (2010b). The endocannabinoid system as a target for the treatment of neuronal damage. Expert Opin. Ther. Targets 14 (4), 387-404. doi:10.1517/ 14728221003709792

Fernández-Ruiz, J., Romero, J., and Ramos, J. A. (2015). Endocannabinoids and neurodegenerative disorders: parkinson's disease, huntington's chorea, alzheimer's disease, and others. Handb. Exp. Pharmacol. 231, 233-259. doi:10.1007/978-3-319-20825-1_8

Fine, P. G., and Rosenfeld, M. J. (2014). Cannabinoids for neuropathic pain. Curr. Pain Headache Rep. 18 (10), 451. doi:10.1007/s11916-014-0451-2

Finseth, T. A., Hedeman, J. L., Brown, R. P., 2nd, Johnson, K. I., Binder, M. S., and Kluger, B. M. (2015). Self-reported efficacy of cannabis and other complementary medicine modalities by parkinson's disease patients in colorado. Evid. Based Complement. Alternat. Med. 2015, 874849. doi:10. $1155 / 2015 / 874849$

Foltynie, T., Cheeran, B., Williams-Gray, C. H., Edwards, M. J., Schneider, S. A., Weinberger, D., et al. (2009). BDNF val66met influences time to onset of levodopa induced dyskinesia in parkinson's disease. J. Neurol. Neurosur. Psychiatry 80 (2), 141-144. doi:10.1136/jnnp.2008.154294

Fowler, C. J. (2013). Transport of endocannabinoids across the plasma membrane and within the cell. FEBS J. 280 (9), 1895-1904. doi:10.1111/febs.12212

Francardo, V., Recchia, A., Popovic, N., Andersson, D., Nissbrandt, H., and Cenci, M. A. (2011). Impact of the lesion procedure on the profiles of motor impairment and molecular responsiveness to L-DOPA in the 6hydroxydopamine mouse model of Parkinson's disease. Neurobiol. Dis. 42 (3), 327-340. doi:10.1016/j.nbd.2011.01.024

Frankel, J. P., Hughes, A., Lees, A. J., and Stern, G. M. (1990). Marijuana for parkinsonian tremor. J. Neurol. Neurosur. Psychiatry 53 (5), 436. doi:10.1136/ jnnp.53.5.436

Galvan, A., Devergnas, A., and Wichmann, T. (2015). Alterations in neuronal activity in basal ganglia-thalamocortical circuits in the parkinsonian state. Front. Neuroanat. 9, 5. doi:10.3389/fnana.2015.00005

García, C., Palomo-Garo, C., García-Arencibia, M., Ramos, J., Pertwee, R., and Fernández-Ruiz, J. (2011). Symptom-relieving and neuroprotective effects of the phytocannabinoid $\Delta^{9}$-THCV in animal models of parkinson's disease. $\mathrm{Br}$. J. Pharmacol. 163 (7), 1495-1506. doi:10.1111/j.1476-5381.2011.01278.x

García, C., Palomo-Garo, C., Gómez-Gálvez, Y., and Fernández-Ruiz, J. (2016). Cannabinoid-dopamine interactions in the physiology and physiopathology of the basal ganglia. Br. J. Pharmacol. 173 (13), 2069-2079. doi:10.1111/bph.13215 
García, M. C., Cinquina, V., Palomo-Garo, C., Rábano, A., and Fernández-Ruiz, J. (2015). Identification of $\mathrm{CB}_{2}$ receptors in human nigral neurons that degenerate in parkinson's disease. Neurosci. Lett. 587, 1-4. doi:10.1016/j.neulet.2014.12.003

García-Arencibia, M., González, S., de Lago, E., Ramos, J. A., Mechoulam, R., and Fernández-Ruiz, J. (2007). Evaluation of the neuroprotective effect of cannabinoids in a rat model of Parkinson's disease: importance of antioxidant and cannabinoid receptor-independent properties. Brain Res. 1134 (1), 162-170. doi:10.1016/j.brainres.2006.11.063

Gerfen, C. R., and Surmeier, D. J. (2011). Modulation of striatal projection systems by dopamine. Annu. Rev. Neurosci. 34, 441-466. doi:10.1146/annurev-neuro061010-113641

Gobira, P. H., Lima, I. V., Batista, L. A., de Oliveira, A. C., Resstel, L. B., Wotjak, C. T., et al. (2017). N-arachidonoyl-serotonin, a dual FAAH and TRPV1 blocker, inhibits the retrieval of contextual fear memory: role of the cannabinoid CB1 receptor in the dorsal hippocampus. J. Psychopharmacol. 31 (6), 750-756. doi:10.1177/0269881117691567

Gomes, F. V., Resstel, L. B., and Guimarães, F. S. (2011). The anxiolytic-like effects of cannabidiol injected into the bed nucleus of the stria terminalis are mediated by 5-HT1A receptors. Psychopharmacology 213 (2-3), 465-473. doi:10.1007/ s00213-010-2036-z

González-Aparicio, R., and Moratalla, R. (2014). Oleoylethanolamide reduces L-DOPA-induced dyskinesia via TRPV1 receptor in a mouse model of Parkinson's disease. Neurobiol. Dis. 62, 416-425. doi:10.1016/j.nbd.2013.10.008

González-Hernández, T., Cruz-Muros, I., Afonso-Oramas, D., Salas-Hernandez, J., and Castro-Hernandez, J. (2010). Vulnerability of mesostriatal dopaminergic neurons in Parkinson's disease. Front. Neuroanat. 4, 140. doi:10.3389/fnana. 2010.00140

Gugliandolo, A., Pollastro, F., Bramanti, P., and Mazzon, E. (2020). Cannabidiol exerts protective effects in an in vitro model of Parkinson's disease activating AKT/mTOR pathway. Fitoterapia 143, 104553. doi:10.1016/j.fitote.2020.104553

Guy, G. W., and Flint, M. E. (2004). A single centre, placebo-controlled, four period, crossover, tolerability study assessing, pharmacodynamic effects, pharmacokinetic characteristics and cognitive profiles of a single dose of three formulations of cannabis based medicine extracts (CBMEs) (GWPD9901), plus a two period tolerability study comparing pharmacodynamic effects and pharmacokinetic characteristics of a single dose of a cannabis based medicine extract given via two administration routes (GWPD9901 EXT). J. Cannabis Ther. 3 (3), 35-77. doi:10.1300/J175v03n03_03

Haber, S. N., and Calzavara, R. (2009). The cortico-basal ganglia integrative network: the role of the thalamus. Brain Res. Bull. 78 (2-3), 69-74. doi:10. 1016/j.brainresbull.2008.09.013

Hald, A., and Lotharius, J. (2005). Oxidative stress and inflammation in Parkinson's disease: is there a causal link?. Exp. Neurol. 193 (2), 279-290. doi:10.1016/j.expneurol.2005.01.013

Hampson, A. J., Grimaldi, M., Axelrod, J., and Wink, D. (1998). Cannabidiol and (-) Delta9-tetrahydrocannabinol are neuroprotective antioxidants. Proc. Natl. Acad. Sci. U.S.A. 95 (14), 8268-8273. doi:10.1073/pnas.95.14.8268

Hanuš, L. O., Meyer, S. M., Muñoz, E., Taglialatela-Scafati, O., and Appendino, G. (2016). Phytocannabinoids: a unified critical inventory. Nat. Prod. Rep. 33 (12), 1357-1392. doi:10.1039/c6np00074f

Harvey, D. J., and Mechoulam, R. (1990). Metabolites of cannabidiol identified in human urine. Xenobiotica 20 (3), 303-320. doi:10.3109/00498259009046849

Hermann, D., Sartorius, A., Welzel, H., Walter, S., Skopp, G., Ende, G., et al. (2007). Dorsolateral prefrontal cortex N-acetylaspartate/total creatine (NAA/tCr) loss in male recreational cannabis users. Biol. Psychiatr. 61 (11), 1281-1289. doi:10. 1016/j.biopsych.2006.08.027

Hernandez-Baltazar, D., Nadella, R., Mireya Zavala-Flores, L., Rosas-Jarquin, C. J., Rovirosa-Hernandez, M. J., and Villanueva-Olivo, A. (2019). Four main therapeutic keys for parkinson's disease: a mini review. Iran. J. Basic Med. Sci. 22 (7), 716-721. doi:10.22038/ijbms.2019.33659.8025

Hickey, P., and Stacy, M. (2012). Adenosine A2A antagonists in parkinson's disease: what's next?. Curr. Neurol. Neurosci. Rep. 12 (4), 376-385. doi:10.1007/ s11910-012-0279-2

Hornykiewicz, O. (1962). Dopamine (3-hydroxytyramine) in the central nervous system and its relation to the Parkinson syndrome in man. Dtsch. Med. Wochenschr. 87, 1807-1810. doi:10.1055/s-0028-1114024
Howells, D. W., Porritt, M. J., Wong, J. Y., Batchelor, P. E., Kalnins, R., Hughes, A. J., et al. (2000). Reduced BDNF mRNA expression in the parkinson's disease substantia nigra. Exp. Neurol. 166 (1), 127-135. doi:10.1006/exnr.2000.7483

Howlett, A. C., Blume, L. C., and Dalton, G. D. (2010). CB(1) cannabinoid receptors and their associated proteins. Curr. Med. Chem. 17 (14), 1382-1393. doi:10.2174/092986710790980023

Howlett, A. C., and Fleming, R. M. (1984). Cannabinoid inhibition of adenylate cyclase. pharmacology of the response in neuroblastoma cell membranes. Mol. Pharmacol. 26 (3), 532-538

Huestis, M. A. (2007). Human cannabinoid pharmacokinetics. Chem. Biodivers. 4 (8), 1770-1804. doi:10.1002/cbdv.200790152

Ibeas Bih, C., Chen, T., Nunn, A. V., Bazelot, M., Dallas, M., and Whalley, B. J. (2015). Molecular targets of cannabidiol in neurological disorders. Neurotherapeutics 12 (4), 699-730. doi:10.1007/s13311-015-0377-3

Indo, H. P., Yen, H. C., Nakanishi, I., Matsumoto, K., Tamura, M., Nagano, Y., et al. (2015). A mitochondrial superoxide theory for oxidative stress diseases and aging. J. Clin. Biochem. Nutr. 56 (1), 1-7. doi:10.3164/jcbn.14-42

Jin, D., Dai, K., Xie, Z., and Chen, J. (2020). Secondary metabolites profiled in cannabis inflorescences, leaves, stem barks, and roots for medicinal purposes. Sci. Rep. 10 (1), 3309. doi:10.1038/s41598-020-60172-6

Jones, N. A., Hill, A. J., Smith, I., Bevan, S. A., Williams, C. M., Whalley, B. J., et al. (2010). Cannabidiol displays antiepileptiform and antiseizure properties in vitro and in vivo. J. Pharmacol. Exp. Ther. 332 (2), 569-577. doi:10.1124/ jpet.109.159145

Kalinderi, K., Bostantjopoulou, S., and Fidani, L. (2016). The genetic background of parkinson's disease: current progress and future prospects. Acta Neurol. Scand. 134 (5), 314-326. doi:10.1111/ane.12563

Kang, S., Cooper, G., Dunne, S. F., Dusel, B., Luan, C. H., Surmeier, D. J., et al. (2012). CaV1.3-selective L-type calcium channel antagonists as potential new therapeutics for parkinson's disease. Nat. Commun. 3, 1146. doi:10.1038/ ncomms 2149

Kano, M., Ohno-Shosaku, T., Hashimotodani, Y., Uchigashima, M., and Watanabe, M. (2009). Endocannabinoid-mediated control of synaptic transmission. Physiol. Rev. 89 (1), 309-380. doi:10.1152/physrev.00019.2008

Kaplan, J. S., Stella, N., Catterall, W. A., and Westenbroek, R. E. (2017). Cannabidiol attenuates seizures and social deficits in a mouse model of Dravet syndrome. Proc. Natl. Acad. Sci. U.S.A. 114 (42), 11229-11234. doi:10.1073/pnas.1711351114

Kathmann, M., Flau, K., Redmer, A., Tränkle, C., and Schlicker, E. (2006). Cannabidiol is an allosteric modulator at mu- and delta-opioid receptors. Naunyn Schmiedebergs Arch. Pharmacol. 372 (5), 354-361. doi:10.1007/ s00210-006-0033-x

Klaus, A., Alves da Silva, J., and Costa, R. M. (2019). What, if, and when to move: basal ganglia circuits and self-paced action initiation. Annu. Rev. Neurosci. 42, 459-483. doi:10.1146/annurev-neuro-072116-031033

Kozela, E., Pietr, M., Juknat, A., Rimmerman, N., Levy, R., and Vogel, Z. (2010). Cannabinoids Delta(9)-tetrahydrocannabinol and cannabidiol differentially inhibit the lipopolysaccharide-activated NF-kappaB and interferon-beta/ STAT proinflammatory pathways in BV-2 microglial cells. J. Biol. Chem. 285 (3), 1616-1626. doi:10.1074/jbc.M109.069294

Lam, P. M., McDonald, J., and Lambert, D. G. (2005). Characterization and comparison of recombinant human and rat TRPV1 receptors: effects of exoand endocannabinoids. Br. J. Anaesth. 94 (5), 649-656. doi:10.1093/bja/aei098

Lanciego, J. L., Luquin, N., and Obeso, J. A. (2012). Functional neuroanatomy of the basal ganglia. Cold Spring Harb Perspect. Med. 2 (12), a009621. doi:10.1101/ cshperspect.a009621

Laprairie, R. B., Bagher, A. M., Kelly, M. E. M., and Denovan-Wright, E. M. (2015). Cannabidiol is a negative allosteric modulator of the cannabinoid CB1 receptor. Br. J. Pharmacol. 172 (20), 4790-4805. doi:10.1111/bph.13250

Lastres-Becker, I., Molina-Holgado, F., Ramos, J. A., Mechoulam, R., and Fernández-Ruiz, J. (2005). Cannabinoids provide neuroprotection against 6hydroxydopamine toxicity in vivo and in vitro: relevance to parkinson's disease. Neurobiol. Dis. 19 (1-2), 96-107. doi:10.1016/j.nbd.2004.11.009

Laun, A. S., and Song, Z. H. (2017). GPR3 and GPR6, novel molecular targets for cannabidiol. Biochem. Biophys. Res. Commun. 490 (1), 17-21. doi:10.1016/j. bbrc.2017.05.165 
Le, W., Wu, J., and Tang, Y. (2016). Protective microglia and their regulation in Parkinson's disease. Front. Mol. Neurosci. 9, 89. doi:10.3389/fnmol.2016. 00089

Liddelow, S. A., Guttenplan, K. A., Clarke, L. E., Bennett, F. C., Bohlen, C. J., Schirmer, L., et al. (2017). Neurotoxic reactive astrocytes are induced by activated microglia. Nature 541 (7638), 481-487. doi:10.1038/nature21029

Ligresti, A., Moriello, A. S., Starowicz, K., Matias, I., Pisanti, S., De Petrocellis, L., et al. (2006). Antitumor activity of plant cannabinoids with emphasis on the effect of cannabidiol on human breast carcinoma. J. Pharmacol. Exp. Ther. 318 (3), 1375-1387. doi:10.1124/jpet.106.105247

Linge, R., Jiménez-Sánchez, L., Campa, L., Pilar-Cuéllar, F., Vidal, R., Pazos, A., et al. (2016). Cannabidiol induces rapid-acting antidepressant-like effects and enhances cortical 5-HT/glutamate neurotransmission: role of 5-HT1A receptors. Neuropharmacology 103, 16-26. doi:10.1016/j.neuropharm.2015. 12.017

Liu, B., and Hong, J. S. (2003). Role of microglia in inflammation-mediated neurodegenerative diseases: mechanisms and strategies for therapeutic intervention. J. Pharmacol. Exp. Ther. 304 (1), 1-7. doi:10.1124/jpet.102.035048

Liu, Q. R., Canseco-Alba, A., Zhang, H. Y., Tagliaferro, P., Chung, M., Dennis, E., et al. (2017). Cannabinoid type 2 receptors in dopamine neurons inhibits psychomotor behaviors, alters anxiety, depression and alcohol preference. Sci. Rep. 7 (1), 17410. doi:10.1038/s41598-017-17796-y

Lobo, M. K., Cui, Y., Ostlund, S. B., Balleine, B. W., and Yang, X. W. (2007). Genetic control of instrumental conditioning by striatopallidal neuron-specific S1P receptor Gpr6. Nat. Neurosci. 10 (11), 1395-1397. doi:10.1038/nn1987

Lotan, I., Treves, T. A., Roditi, Y., and Djaldetti, R. (2014). Cannabis (medical marijuana) treatment for motor and non-motor symptoms of Parkinson disease: an open-label observational study. Clin. Neuropharmacol. 37 (2), 41-44. doi:10.1097/WNF.0000000000000016

Luquin, M. R., Scipioni, O., Vaamonde, J., Gershanik, O., and Obeso, J. A. (1992). Levodopa-induced dyskinesias in parkinson's disease: clinical and pharmacological classification. Mov. Disord. 7 (2), 117-124. doi:10.1002/ mds. 870070204

Mackie, K. (2006). Mechanisms of CB1 receptor signaling: endocannabinoid modulation of synaptic strength. Int. J. Obes. 30 (Suppl. 1), S19-S23. doi:10. 1038/sj.ijo.08032733

Magen, I., Avraham, Y., Ackerman, Z., Vorobiev, L., Mechoulam, R., and Berry, E. M. (2010). Cannabidiol ameliorates cognitive and motor impairments in bileduct ligated mice via 5-HT1A receptor activation. Br. J. Pharmacol. 159 (4), 950-957. doi:10.1111/j.1476-5381.2009.00589.x

Malek, N., Kanavou, S., Lawton, M. A., Pitz, V., Grosset, K. A., Bajaj, N., et al. (2019). L-dopa responsiveness in early parkinson's disease is associated with the rate of motor progression. Park. Relat. Disord. 65, 55-61. doi:10.1016/j. parkreldis.2019.05.022

Malfait, A. M., Gallily, R., Sumariwalla, P. F., Malik, A. S., Andreakos, E., Mechoulam, R., et al. (2000). The nonpsychoactive cannabis constituent cannabidiol is an oral anti-arthritic therapeutic in murine collagen-induced arthritis. Proc. Natl. Acad. Sci. U.S.A. 97 (17), 9561-9566. doi:10.1073/pnas. 160105897

Marconi, R., Lefebvre-Caparros, D., Bonnet, A. M., Vidailhet, M., Dubois, B., and Agid, Y. (1994). Levodopa-induced dyskinesias in Parkinson's disease phenomenology and pathophysiology. Mov. Disord. 9 (1), 2-12. doi:10.1002/ mds.870090103. PMID: 8139601

Martinez, A. A., Morgese, M. G., Pisanu, A., Macheda, T., Paquette, M. A., Seillier, A., et al. (2015). Activation of PPAR gamma receptors reduces levodopainduced dyskinesias in 6-OHDA-lesioned rats. Neurobiol. Dis. 74, 295-304. doi:10.1016/j.nbd.2014.11.024

Martinez, A., Macheda, T., Morgese, M. G., Trabace, L., and Giuffrida, A. (2012). The cannabinoid agonist WIN55212-2 decreases L-DOPA-induced PKA activation and dyskinetic behavior in 6-OHDA-treated rats. Neurosci. Res. 72 (3), 236-242. doi:10.1016/j.neures.2011.12.006

Martinez, B., and Peplow, P. V. (2018). Neuroprotection by immunomodulatory agents in animal models of parkinson's disease. Neural Regen Res 13 (9), 1493-1506. doi:10.4103/1673-5374.237108

Martínez-Pinilla, E., Varani, K., Reyes-Resina, I., Angelats, E., Vincenzi, F., Ferreiro-Vera, C., et al. (2017). Binding and signaling studies disclose a potential allosteric site for cannabidiol in cannabinoid CB2 receptors. Front. Pharmacol. 8, 744. doi:10.3389/fphar.2017.00744
Matsuda, L. A., Lolait, S. J., Brownstein, M. J., Young, A. C., and Bonner, T. I. (1990). Structure of a cannabinoid receptor and functional expression of the cloned cDNA. Nature 346 (6284), 561-564. doi:10.1038/346561a0

McGeer, P. L., Yasojima, K., and McGeer, E. G. (2001). Inflammation in parkinson's disease. Adv. Neurol. 86, 83-89. http://pascal-francis.inist.fr/ vibad/index.php?action $=$ getRecordDetail\&idt $=14673148$

McHugh, D., Roskowski, D., Xie, S., and Bradshaw, H. B. (2014). $\Delta(9)$-THC and $\mathrm{N}$-arachidonoyl glycine regulate BV-2 microglial morphology and cytokine release plasticity: implications for signaling at GPR18. Front. Pharmacol. 4, 162. doi:10.3389/fphar.2013.00162

McPartland, J. M. (2018). Cannabis systematics at the levels of family, genus, and species. Cannabis Cannabinoid Res. 3 (1), 203-212. doi:10.1089/can.2018.0039

McPartland, J. M., Glass, M., and Pertwee, R. G. (2007). Meta-analysis of cannabinoid ligand binding affinity and receptor distribution: interspecies differences. Br. J. Pharmacol. 152 (5), 583-593. doi:10.1038/sj.bjp.0707399

Mecha, M., Feliú, A., Iñigo, P. M., Mestre, L., Carrillo-Salinas, F. J., and Guaza, C. (2013). Cannabidiol provides long-lasting protection against the deleterious effects of inflammation in a viral model of multiple sclerosis: a role for A2A receptors. Neurobiol. Dis. 59, 141-150. doi:10.1016/j.nbd.2013.06.016

Mechoulam, R., Ben-Shabat, S., Hanus, L., Ligumsky, M., Kaminski, N. E., Schatz, A. R., et al. (1995). Identification of an endogenous 2-monoglyceride, present in canine gut, that binds to cannabinoid receptors. Biochem. Pharmacol. 50 (1), 83-90. doi:10.1016/0006-2952(95)00109-d

Mechoulam, R., Parker, L. A., and Gallily, R. (2002). Cannabidiol: an overview of some pharmacological aspects. J. Clin. Pharmacol. 42 (S1), 11S-19S. doi:10. 1002/j.1552-4604.2002.tb05998.x

Mechoulam, R., and Parker, L. A. (2013). The endocannabinoid system and the brain. Annu. Rev. Psychol. 64, 21-47. doi:10.1146/annurev-psych-113011143739

Mechoulam, R., Tchilibon, S., Fride, E., Hanus, L., Breuer, A., and Gallily, R. (2010). Pharmaceutical compositions comprising cannabidiol derivatives. Jerusalem, IL: U.S. Patent documents, U.S. Patent No 7759526.

Mezey, E., Tóth, Z. E., Cortright, D. N., Arzubi, M. K., Krause, J. E., Elde, R., et al. (2000). Distribution of mRNA for vanilloid receptor subtype 1 (VR1), and VR1like immunoreactivity, in the central nervous system of the rat and human. Proc. Natl. Acad. Sci. U.S.A. 97 (7), 3655-3660. doi:10.1073/pnas.060496197

Mhyre, T. R., Boyd, J. T., Hamill, R. W., and Maguire-Zeiss, K. A. (2012). Parkinson's disease. Subcell. Biochem. 65, 389-455. doi:10.1007/978-94-0075416-4_16

Millar, S. A., Stone, N. L., Bellman, Z. D., Yates, A. S., England, T. J., and O'Sullivan, S. E. (2019). A systematic review of cannabidiol dosing in clinical populations. Br. J. Clin. Pharmacol. 85 (9), 1888-1900. doi:10.1111/bcp.14038

Millar, S. A., Stone, N. L., Yates, A. S., and O'Sullivan, S. E. (2018). A systematic review on the pharmacokinetics of cannabidiol in humans. Front. Pharmacol. 9 , 1365. doi:10.3389/fphar.2018.01365

Molina-Holgado, F., Pinteaux, E., Moore, J. D., Molina-Holgado, E., Guaza, C., Gibson, R. M., et al. (2003). Endogenous interleukin-1 receptor antagonist mediates anti-inflammatory and neuroprotective actions of cannabinoids in neurons and glia. J. Neurosci. 23 (16), 6470-6474. doi:10.1523/JNEUROSCI.2316-06470.2003

Mones, R. J., Elizan, T. S., and Siegel, G. J. (1971). Analysis of L-dopa induced dyskinesias in 51 patients with parkinsonism. J. Neurol. Neurosurg. Psychiatry 34 (6), 668-673. doi:10.1136/jnnp.34.6.668

Moosmann, B., and Behl, C. (2002). Antioxidants as treatment for neurodegenerative disorders. Expet Opin. Invest. Drugs 11 (10), 1407-1435. doi:10.1517/13543784.11.10.1407

Morales, P., Hurst, D. P., and Reggio, P. H. (2017). Molecular targets of the phytocannabinoids: a complex picture. Prog. Chem. Org. Nat. Prod. 103, 103-131. doi:10.1007/978-3-319-45541-9_4

Morales, P., Lago-Fernandez, A., Hurst, D. P., Sotudeh, N., Brailoiu, E., Reggio, P. H., et al. (2020). Therapeutic exploitation of GPR18: beyond the cannabinoids?. J. Med. Chem. [Epub ahead of print]. doi:10.1021/acs. jmedchem.0c00926

Morales, P., and Reggio, P. H. (2017). An update on non-CB1, non-CB2 cannabinoid related G-protein-coupled receptors. Cannabis Cannabinoid Res. 2 (1), 265-273. doi:10.1089/can.2017.0036

Morano, A., Fanella, M., Albini, M., Cifelli, P., Palma, E., Giallonardo, A. T., et al. (2020). Cannabinoids in the treatment of epilepsy: current status and 
future prospects. Neuropsychiatric Dis. Treat. 16, 381-396. doi:10.2147/ NDT.S203782

Morgese, M. G., Cassano, T., Cuomo, V., and Giuffrida, A. (2007). Anti-dyskinetic effects of cannabinoids in a rat model of Parkinson's disease: role of $\mathrm{CB}(1)$ and TRPV1 receptors. Exp. Neurol. 208 (1), 110-119. doi:10.1016/j.expneurol.2007. 07.021

Muñoz, A., Li, Q., Gardoni, F., Marcello, E., Qin, C., Carlsson, T., et al. (2008). Combined 5-HT1A and 5-HT1B receptor agonists for the treatment of L-DOPA-induced dyskinesia. Brain 131 (Pt 12), 3380-3394. doi:10.1093/ brain/awn235

Munro, S., Thomas, K. L., and Abu-Shaar, M. (1993). Molecular characterization of a peripheral receptor for cannabinoids. Nature 365 (6441), 61-65. doi:10.1038/ $365061 \mathrm{a} 0$

Nadal, X., Del Río, C., Casano, S., Palomares, B., Ferreiro-Vera, C., Navarrete, C., et al. (2017). Tetrahydrocannabinolic acid is a potent PPAR $\gamma$ agonist with neuroprotective activity. Br. J. Pharmacol. 174 (23), 4263-4276. doi:10.1111/bph.14019

Navarro, G., Reyes-Resina, I., Rivas-Santisteban, R., Sánchez de Medina, V., Morales, P., Casano, S., et al. (2018). Cannabidiol skews biased agonism at cannabinoid $\mathrm{CB} 1$ and $\mathrm{CB} 2$ receptors with smaller effect in CB1-CB2 heteroreceptor complexes. Biochem. Pharmacol. 157, 148-158. doi:10.1016/j. bcp.2018.08.046

O'Sullivan, S. E., Sun, Y., Bennett, A. J., Randall, M. D., and Kendall, D. A. (2009). Time-dependent vascular actions of cannabidiol in the rat aorta. Eur. J. Pharmacol. 612 (1-3), 61-68. doi:10.1016/j.ejphar.2009.03.010

Oeckl, P., Hengerer, B., and Ferger, B. (2014). G-protein coupled receptor 6 deficiency alters striatal dopamine and cAMP concentrations and reduces dyskinesia in a mouse model of Parkinson's disease. Exp. Neurol. 257, 1-9. doi:10.1016/j.expneurol.2014.04.010

Oh, Y. T., Lee, J. Y., Lee, J., Lee, J. H., Kim, J. E., Ha, J., et al. (2010). Oleamide suppresses lipopolysaccharide-induced expression of iNOS and COX-2 through inhibition of NF-kappaB activation in BV2 murine microglial cells. Neurosci. Lett. 474 (3), 148-153. doi:10.1016/j.neulet.2010.03.026

Olivares, D., Deshpande, V. K., Shi, Y., Lahiri, D. K., Greig, N. H., Rogers, J. T., et al. (2012). N-methyl D-aspartate (NMDA) receptor antagonists and memantine treatment for Alzheimer's disease, vascular dementia and parkinson's disease. Curr. Alzheimer Res. 9 (6), 746-758. doi:10.2174/156720512801322564

Pahwa, R., Isaacson, S., Jimenez-Shaheed, J., Malaty, I. A., Deik, A., Johnson, R., et al. (2019). Impact of dyskinesia on activities of daily living in Parkinson's disease: results from pooled phase 3 ADS-5102 clinical trials. Park. Relat. Disord. 60, 118-125. doi:10.1016/j.parkreldis.2018.09.005

Pandey, S., and Srivanitchapoom, P. (2017). Levodopa-induced dyskinesia: clinical features, pathophysiology, and medical management. Ann. Indian Acad. Neurol. 20 (3), 190-198. doi:10.4103/aian.AIAN_239_17

Pandolfo, P., Silveirinha, V., dos Santos-Rodrigues, A., Venance, L., Ledent, C., Takahashi, R. N., et al. (2011). Cannabinoids inhibit the synaptic uptake of adenosine and dopamine in the rat and mouse striatum. Eur. J. Pharmacol. 655, 38-45. doi:10.1016/j.ejphar.2011.01.013

Pang, S. Y., Ho, P. W., Liu, H. F., Leung, C. T., Li, L., Chang, E., et al. (2019). The interplay of aging, genetics and environmental factors in the pathogenesis of parkinson's disease. Transl. Neurodegener. 8, 23. doi:10.1186/s40035-019-0165-9

Park, H. Y., Kang, Y. M., Kang, Y., Park, T. S., Ryu, Y. K., Hwang, J. H., et al. (2014). Inhibition of adenylyl cyclase type 5 prevents L-DOPA-induced dyskinesia in an animal model of Parkinson's disease. J. Neurosci. 34 (35), 11744-11753. doi:10.1523/JNEUROSCI.0864-14.2014

Paton, W. D., and Pertwee, R. G. (1972). Effect of cannabis and certain of its constituents on pentobarbitone sleeping time and phenazone metabolism. $\mathrm{Br}$. J. Pharmacol. 44 (2), 250-261. doi:10.1111/j.1476-5381.1972.tb07261.x

Peres, F. F., Levin, R., Suiama, M. A., Diana, M. C., Gouvêa, D. A., Almeida, V., et al. (2016). Cannabidiol prevents motor and cognitive impairments induced by reserpine in rats. Front. Pharmacol. 7, 343. doi:10.3389/fphar.2016.00343

Peres, F. F., Lima, A. C., Hallak, J., Crippa, J. A., Silva, R. H., and Abílio, V. C. (2018). Cannabidiol as a promising strategy to treat and prevent movement disorders?. Front. Pharmacol. 9, 482. doi:10.3389/fphar.2018.00482

Perez-Reyes, M., Wagner, D., Wall, M. E., and Davis, K. H. (1976). "Intravenous administration of cannabinoids on intraocular pressure," in The pharmacology of marihuana. Editors M. C. Braude and S. Szara (New York: Raven Press), 829-832.
Pertwee, R. G., and Ross, R. A. (2002). Cannabinoid receptors and their ligands. Prostaglandins Leukot. Essent. Fatty Acids 66 (2-3), 101-121. doi:10.1054/plef.2001.0341

Pertwee, R. G. (2004). "The pharmacology and therapeutic potential of cannabidiol," in Cannabinoids. Editor V. Di Marzo (New York: Kluwer Academic/Plenum Publishers), 32-83.

Pertwee, R. G. (1972). The ring test: a quantitative method for assessing the 'cataleptic' effect of cannabis in mice. Br. J. Pharmacol. 46 (4), 753-763. doi:10. 1111/j.1476-5381.1972.tb06900.x

Pisanu, A., Boi, L., Mulas, G., Spiga, S., Fenu, S., and Carta, A. R. (2018). Neuroinflammation in L-DOPA-induced dyskinesia: beyond the immune function. J. Neural. Transm. 125 (8), 1287-1297. doi:10.1007/s00702-0181874-4

Poddar, M. K., and Dewey, W. L. (1980). Effects of cannabinoids on catecholamine uptake and release in hypothalamic and striatal synaptosomes. J. Pharmacol. Exp. Ther. 214 (1), 63-67

Prud'homme, M., Cata, R., and Jutras-Aswad, D. (2015). Cannabidiol as an intervention for addictive behaviors: a systematic review of the evidence. Subst. Abuse 9, 33-38. doi:10.4137/SART.S25081

Putterman, D. B., Munhall, A. C., Kozell, L. B., Belknap, J. K., and Johnson, S. W. (2007). Evaluation of levodopa dose and magnitude of dopamine depletion as risk factors for levodopa-induced dyskinesia in a rat model of parkinson's disease. J. Pharmacol. Exp. Ther. 323 (1), 277-284. doi:10.1124/jpet.107.126219

Randy, L. H., and Guoying, B. (2007). Agonism of peroxisome proliferator receptor-gamma may have therapeutic potential for neuroinflammation and Parkinson's disease. Curr. Neuropharmacol. 5 (1), 35-46. doi:10.2174/ 157015907780077123

Rascol, O., Fabre, N., Brefel-Courbon, C., Ory-Mange, F., and Perez-Lloret, S. (2010). "Dyskinesias," in Encyclopedia of movement disorders. Editors K. Kompoliti and L. Verhagen (New York, NY: Elsevier Academic Press), 350-361.

Ren, Y., Whittard, J., Higuera-Matas, A., Morris, C. V., and Hurd, Y. L. (2009). Cannabidiol, a nonpsychotropic component of cannabis, inhibits cue-induced heroin seeking and normalizes discrete mesolimbic neuronal disturbances. J. Neurosci. 29 (47), 14764-14769. doi:10.1523/JNEUROSCI.4291-09.2009

Rimmerman, N., Juknat, A., Kozela, E., Levy, R., Bradshaw, H. B., and Vogel, Z. (2011). The non-psychoactive plant cannabinoid, cannabidiol affects cholesterol metabolism-related genes in microglial cells. Cell. Mol. Neurobiol. 31 (6), 921-930. doi:10.1007/s10571-011-9692-3

Rock, E. M., Bolognini, D., Limebeer, C. L., Cascio, M. G., Anavi-Goffer, S., Fletcher, P. J., et al. (2012). Cannabidiol, a non-psychotropic component of cannabis, attenuates vomiting and nausea-like behaviour via indirect agonism of $5-\mathrm{HT}(1 \mathrm{~A})$ somatodendritic autoreceptors in the dorsal raphe nucleus. $\mathrm{Br}$. J. Pharmacol. 165 (8), 2620-2634. doi:10.1111/j.1476-5381.2011.01621.x

Rodnitzky, R. L. (1999). Can calcium antagonists provide a neuroprotective effect in parkinson's disease?. Drugs 57 (6), 845-849. doi:10.2165/00003495199957060-00001

Rosin, D. L., Hettinger, B. D., Lee, A., and Linden, J. (2003). Anatomy of adenosine A2A receptors in brain: morphological substrates for integration of striatal function. Neurol. 61 (11 Suppl. 6), S12-S18. doi:10.1212/01.wnl.0000095205.33940.99

Ross, R. A. (2003). Anandamide and vanilloid TRPV1 receptors. Br. J. Pharmacol. 140 (5), 790-801. doi:10.1038/sj.bjp.0705467

Russo, E. B., Burnett, A., Hall, B., and Parker, K. K. (2005). Agonistic properties of cannabidiol at 5-HT1a receptors. Neurochem. Res. 30 (8), 1037-1043. doi:10. 1007/s11064-005-6978-1

Russo, E. B. (2007). History of cannabis and its preparations in saga, science, and sobriquet. Chem. Biodivers. 4 (8), 1614-1648. doi:10.1002/cbdv.200790144

Ryberg, E., Larsson, N., Sjögren, S., Hjorth, S., Hermansson, N. O., Leonova, J., et al. (2007). The orphan receptor GPR55 is a novel cannabinoid receptor. $B r$. J. Pharmacol. 152 (7), 1092-1101. doi:10.1038/sj.bjp.0707460

Sales, A. J., Fogaça, M. V., Sartim, A. G., Pereira, V. S., Wegener, G., Guimarães, F. S., et al. (2019). Cannabidiol induces rapid and sustained antidepressant-like effects through increased BDNF signaling and synaptogenesis in the prefrontal cortex. Mol. Neurobiol. 56 (2), 1070-1081. doi:10.1007/s12035-018-1143-4

Samarut, É., Nixon, J., Kundap, U. P., Drapeau, P., and Ellis, L. D. (2019). Single and synergistic effects of cannabidiol and $\Delta$-9-tetrahydrocannabinol on zebrafish models of neuro-hyperactivity. Front. Pharmacol. 10, 226. doi:10. 3389/fphar.2019.00226 
Santini, E., Valjent, E., Usiello, A., Carta, M., Borgkvist, A., Girault, J. A., et al. (2007). Critical involvement of cAMP/DARPP-32 and extracellular signalregulated protein kinase signaling in L-DOPA-induced dyskinesia. J. Neurosci. 27 (26), 6995-7005. doi:10.1523/JNEUROSCI.0852-07.2007

Santos, N. A., Martins, N. M., Sisti, F. M., Fernandes, L. S., Ferreira, R. S., Queiroz, R. H., et al. (2015). The neuroprotection of cannabidiol against MPP'-induced toxicity in PC12 cells involves trkA receptors, upregulation of axonal and synaptic proteins, neuritogenesis, and might be relevant to Parkinson's disease. Toxicol. Vitro 30 (1 Pt B), 231-240. doi:10.1016/j.tiv.2015.11.004

Savica, R., Grossardt, B. R., Bower, J. H., Ahlskog, J. E., Mielke, M. M., and Rocca, W. A. (2017). Incidence and time trends of drug-induced parkinsonism: a 30-year population-based study. Mov. Disord. 32 (2), 227-234. doi:10.1002/mds.26839

Schapira, A. H., Olanow, C. W., Greenamyre, J. T., and Bezard, E. (2014). Slowing of neurodegeneration in Parkinson's disease and Huntington's disease: future therapeutic perspectives. Lancet 384 (9942), 545-555. doi:10.1016/S01406736(14)61010-2

Schiffmann, S. N., Fisone, G., Moresco, R., Cunha, R. A., and Ferré, S. (2007). Adenosine A2A receptors and basal ganglia physiology. Prog. Neurobiol. 83 (5), 277-292. doi:10.1016/j.pneurobio.2007.05.001

Schönhofen, P., de Medeiros, L. M., Bristot, I. J., Lopes, F. M., De Bastiani, M. A., Kapczinski, F., et al. (2015). Cannabidiol exposure during neuronal differentiation sensitizes cells against redox-active neurotoxins. Mol. Neurobiol. 52 (1), 26-37. doi:10.1007/s12035-014-8843-1

Schwarzschild, M. A., Agnati, L., Fuxe, K., Chen, J. F., and Morelli, M. (2006). Targeting adenosine A2A receptors in Parkinson's disease. Trends Neurosci. 29 (11), 647-654. doi:10.1016/j.tins.2006.09.004

Sieradzan, K. A., Fox, S. H., Hill, M., Dick, J. P., Crossman, A. R., and Brotchie, J. M. (2001). Cannabinoids reduce levodopa-induced dyskinesia in Parkinson's disease: a pilot study. Neurology 57 (11), 2108-2111. doi:10.1212/wnl.57.11.2108

Smith, S. R., Terminelli, C., and Denhardt, G. (2000). Effects of cannabinoid receptor agonist and antagonist ligands on production of inflammatory cytokines and anti-inflammatory interleukin-10 in endotoxemic mice. J. Pharmacol. Exp. Ther. 293 (1), 136-150

Snider, S. R., and Consroe, P. (1985). Beneficial and adverse effects of cannabidiol in a Parkinson patient with sinemet-induced dystonic dyskinesia. Neurology 35 (Suppl. 1), 201

Sonego, A. B., Prado, D. S., Vale, G. T., Sepulveda-Diaz, J. E., Cunha, T. M., Tirapelli, C. R., et al. (2018). Cannabidiol prevents haloperidol-induced vacuos chewing movements and inflammatory changes in mice via $\operatorname{PPAR} \gamma$ receptors. Brain Behav. Immun. 74, 241-251. doi:10.1016/j.bbi.2018.09.014

Stampanoni Bassi, M., Sancesario, A., Morace, R., Centonze, D., and Iezzi, E. (2017). Cannabinoids in parkinson's disease. Cannabis Cannabinoid Res. 2 (1), 21-29. doi:10.1089/can.2017.0002

Stella, N. (2010). Cannabinoid and cannabinoid-like receptors in microglia, astrocytes, and astrocytomas. Glia 58 (9), 1017-1030. doi:10.1002/glia.20983

Stott, C. G., White, L., Wright, S., Wilbraham, D., and Guy, G. W. (2013). A phase I study to assess the single and multiple dose pharmacokinetics of THC/CBD oromucosal spray. Eur. J. Clin. Pharmacol. 69 (5), 1135-1147. doi:10.1007/ s00228-012-1441-0

Subramaniam, S. R., and Federoff, H. J. (20172017). Targeting microglial activation states as a therapeutic avenue in Parkinson's disease. Front. Aging Neurosci. 9, 176. doi:10.3389/fnagi.2017.00176

Sugiura, T., Kondo, S., Sukagawa, A., Nakane, S., Shinoda, A., Itoh, K., et al. (1995). 2-Arachidonoylglycerol: a possible endogenous cannabinoid receptor ligand in brain. Biochem. Biophys. Res. Commun. 215 (1), 89-97. doi:10.1006/bbrc. 1995.2437

Swortwood, M. J., Newmeyer, M. N., Andersson, M., Abulseoud, O. A., Scheidweiler, K. B., and Huestis, M. A. (2017). Cannabinoid disposition in oral fluid after controlled smoked, vaporized, and oral cannabis administration. Drug Test. Anal. 9 (6), 905-915. doi:10.1002/dta.2092

Tang, Y., and Le, W. (2016). Differential roles of M1 and M2 microglia in neurodegenerative diseases. Mol. Neurobiol. 53 (2), 1181-1194. doi:10.1007/ s12035-014-9070-5

Thabuis, C., Tissot-Favre, D., Bezelgues, J. B., Martin, J. C., Cruz-Hernandez, C., Dionisi, F., et al. (2008). Biological functions and metabolism of oleoylethanolamide. Lipids 43 (10), 887-894. doi:10.1007/s11745-008-3217-y

Tham, M., Yilmaz, O., Alaverdashvili, M., Kelly, M., Denovan-Wright, E. M., and Laprairie, R. B. (2019). Allosteric and orthosteric pharmacology of cannabidiol and cannabidiol-dimethylheptyl at the type 1 and type 2 cannabinoid receptors. Br. J. Pharmacol. 176 (10), 1455-1469. doi:10.1111/bph.14440

Thanvi, B., Lo, N., and Robinson, T. (2007). Levodopa-induced dyskinesia in Parkinson's disease: clinical features, pathogenesis, prevention and treatment. Postgrad. Med. 83 (980), 384-388. doi:10.1136/pgmj.2006.054759

Thomas, A., Baillie, G. L., Phillips, A. M., Razdan, R. K., Ross, R. A., and Pertwee, R. G. (2007). Cannabidiol displays unexpectedly high potency as an antagonist of CB1 and CB2 receptor agonists in vitro. Br. J. Pharmacol. 150 (5), 613-623. doi:10.1038/sj.bjp.0707133

Tran, T. N., Vo, T., Frei, K., and Truong, D. D. (2018). Levodopa-induced dyskinesia: clinical features, incidence, and risk factors. J. Neural. Transm. 125 (8), 1109-1117. doi:10.1007/s00702-018-1900-6

Valvassori, S. S., Bavaresco, D. V., Scaini, G., Varela, R. B., Streck, E. L., Chagas, M. H., et al. (2013). Acute and chronic administration of cannabidiol increases mitochondrial complex and creatine kinase activity in the rat brain. Braz. J. Psychiatry 35 (4), 380-386. doi:10.1590/1516-4446-2012-0886

Varlet, V., Concha-Lozano, N., Berthet, A., Plateel, G., Favrat, B., De Cesare, M., et al. (2016). Drug vaping applied to cannabis: is "Cannavaping" a therapeutic alternative to marijuana?. Sci. Rep. 6, 25599. doi:10.1038/srep255999

Venderová, K., Růzicka, E., Vorísek, V., and Visnovský, P. (2004). Survey on cannabis use in parkinson's disease: subjective improvement of motor symptoms. Mov. Disord. 19 (9), 1102-1106. doi:10.1002/mds.20111

Vijayakumar, D., and Jankovic, J. (2016). Drug-induced dyskinesia, Part 1: treatment of levodopa-induced dyskinesia. Drugs 76 (7), 759-777. doi:10. 1007/s40265-016-0566-3

Walter, L., Franklin, A., Witting, A., Wade, C., Xie, Y., Kunos, G., et al. (2003). Nonpsychotropic cannabinoid receptors regulate microglial cell migration. J. Neurosci. 23 (4), 1398-1405. doi:10.1523/JNEUROSCI.23-04-01398.2003

Wang, M., Wang, Y. H., Avula, B., Radwan, M. M., Wanas, A. S., van Antwerp, J., et al. (2016). Decarboxylation study of acidic cannabinoids: a novel approach using ultrahigh-performance supercritical fluid chromatography/photodiode array-mass spectrometry. Cannabis Cannabinoid Res. 1 (1), 262-271. doi:10.1089/can.2016.0020

Wang, Y., Zhang, G. J., Sun, Y. N., Yao, L., Wang, H. S., Du, C. X., et al. (2018). Identification of metabolite biomarkers for L-DOPA-induced dyskinesia in a rat model of parkinson's disease by metabolomic technology. Behav. Brain Res. 347, 175-183. doi:10.1016/j.bbr.2018.03.020

Watzl, B., Scuderi, P., and Watson, R. R. (1991). Marijuana components stimulate human peripheral blood mononuclear cell secretion of interferon-gamma and suppress interleukin-1 alpha in vitro. Int. J. Immunopharm. 13 (8), 1091-1097. doi:10.1016/0192-0561(91)90160-9

Yates, M. L., and Barker, E. L. (2009). "Organized trafficking of anandamide and related lipids," in Vitamins \& hormones. Editor G. Litwack (Cambridge, Massachusetts: Academic Press). 25-53.

Zajicek, J. P., and Apostu, V. I. (2011). Role of cannabinoids in multiple sclerosis. CNS Drugs 25 (3), 187-201. doi:10.2165/11539000-000000000-00000

Zanelati, T. V., Biojone, C., Moreira, F. A., Guimarães, F. S., and Joca, S. R. (2010). Antidepressant-like effects of cannabidiol in mice: possible involvement of 5-HT1A receptors. Br. J. Pharmacol. 159 (1), 122-128. doi:10.1111/j.1476-5381.2009.00521.x

Zendulka, O., Dovrtělová, G., Nosková, K., Turjap, M., Šulcová, A., Hanuš, L., et al. (2016). Cannabinoids and cytochrome P450 interactions. Curr. Drug Metabol. 17 (3), 206-226. doi:10.2174/1389200217666151210142051

Zgair, A., Wong, J. C., Lee, J. B., Mistry, J., Sivak, O., Wasan, K. M., et al. (2016). Dietary fats and pharmaceutical lipid excipients increase systemic exposure to orally administered cannabis and cannabis-based medicines. Am. J. Transl. Res. 8 (8), 3448-3459. http://www.ncbi.nlm.nih.gov/pmc/articles/PMC5009397/

Zhou, X., Guo, J., Sun, Q., Xu, Q., Pan, H., Yu, R., et al. (2019). Factors associated with dyskinesia in parkinson's disease in mainland china. Front. Neurol. 10, 477. doi:10.3389/fneur.2019.00477

Zuardi, A. W., Shirakawa, I., Finkelfarb, E., and Karniol, I. G. (1982). Action of cannabidiol on the anxiety and other effects produced by delta 9-THC in normal subjects. Psychopharmacol. 76 (3), 245-250. doi:10.1007/BF00432554

Zuardi, A. W., Crippa, J. A., Hallak, J. E., Moreira, F. A., and Guimarães, F. S. (2006). Cannabidiol, a cannabis sativa constituent, as an antipsychotic drug. Braz. J. Med. Biol. Res. 39 (4), 421-429. doi:10.1590/s0100-879x2006000400001

Zuardi, A. W., Crippa, J. A., Hallak, J. E., Pinto, J. P., Chagas, M. H., Rodrigues, G. G., et al. (2009). Cannabidiol for the treatment of psychosis in parkinson's disease. J. Psychopharmacol. 23 (8), 979-983. doi: $10.1177 / 0269881108096519$ 
Conflict of Interest: The authors declare that the research was conducted in the absence of any commercial or financial relationships that could be construed as a potential conflict of interest.

Copyright (c) 2020 Patricio, Morales-Andrade, Patricio-Martínez and Limón. This is an open-access article distributed under the terms of the Creative Commons
Attribution License (CC $B Y$ ). The use, distribution or reproduction in other forums is permitted, provided the original author(s) and the copyright owner(s) are credited and that the original publication in this journal is cited, in accordance with accepted academic practice. No use, distribution or reproduction is permitted which does not comply with these terms. 